\title{
El debido proceso en la jurisprudencia de la Corte Interamericana
}

Carolina Loayza Tamayo* http://dx.doi.org/10.21503/lex.v10i9.319

Profesora principal de Derecho Internacional Público de la Universidad de Lima. Abogada litigante ante el Sistema Interamericano de Protección de Derechos Humanos.

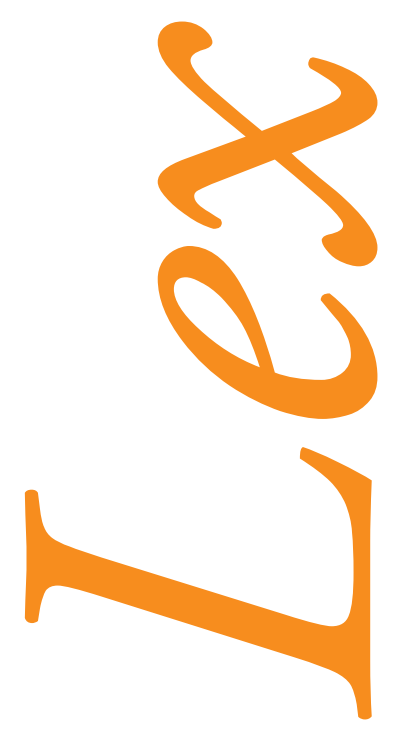



1 presente trabajo solo es una sistematización no concluida de las sentencias de la Corte Interamericana de Derechos Humanos sobre el debido proceso, y busca ayudar a visualizar los criterios que sobre esta materia ha establecido ese importante órgano jurisdiccional conformante de Sistema Interamericano de Protección de los Derechos Humanos, que nuestros tribunales nacionales deben observar, en tanto nuestro país ha participado en su creación y se ha comprometido cumplir. Las sentencias del Tribunal Constitucional peruano ya nos permiten comprobar la observancia de este compromiso.

\section{GENERALIDADES}

\section{DEFINICIÓN}

El debido proceso, llamado por la Corte Interamericana de Derechos Humanos (en adelante Corte, Corte Interamericana, Corte IDH) "derecho de defensa procesal", ${ }^{1}$ consiste en "...el derecho de toda persona a ser oída con las debidas garantías y dentro de un plazo razonable por un juez o tribunal competente, independiente e imparcial, establecido con anterioridad por la ley en la sustanciación de cualquier acusación penal en su contra o para la determinación de sus derechos de carácter civil, laboral, fiscal u otro cualquiera”, ${ }^{2}$ identificando el debido proceso con el contenido del artículo 8 de la Convención Americana, el que debe ser interpretado de manera amplia. ${ }^{3}$ Es decir, su interpretación debe apoyarse tanto en el texto literal de la norma como en su espíritu, y con exclusión de otros derechos y

1 Corte IDH. Caso Genie Lacayo. Sentencia de 29 de enero de 1997, párr. 74. La Corte IDH, refiriéndose al artículo 8 de la Convención Americana sobre DH, dijo: “... que se refiere a las garantías judiciales consagra los lineamientos del llamado 'debido proceso legal' o 'derecho de defensa procesal...".

2 Ibid.

3 Corte IDH. Caso Las Palmeras. Sentencia de 6 de abril de 2005, párr. 58; Caso Durand y Ugarte, párr. 128; Caso Blake, párr. 96: "96. Este Tribunal considera que el artículo 8.1 de la Convención debe interpretarse de manera amplia de modo que dicha interpretación se apoye tanto en el texto literal de esa norma como en su espíritu, y debe ser apreciado de acuerdo con el artículo 29, inciso c) de la Convención, según el cual ninguna disposición de la misma puede interpretarse con exclusión de otros derechos y garantías inherentes al ser humano o que se deriven de la forma democrática representativa de gobierno". 
garantías inherentes al ser humano o que se deriven de la forma democrática representativa de gobierno. ${ }^{4}$

Para la Corte, el debido proceso abarca las "condiciones que deben cumplirse para asegurar la adecuada defensa de aquellos cuyos derechos u obligaciones están bajo consideración judicial"; 5 a efectos de "que las personas estén en condiciones de defender adecuadamente sus derechos ante cualquier tipo de acto del Estado que pueda afectarlos"; 6 constituyendo un límite infranqueable a la discrecionalidad del poder público, en cualquier materia. ${ }^{7}$

\section{NATURALEZA: DERECHO HUMANO DE NATURALEZA PROGRESIVA Y EVOLUTIVA}

Aunque nadie discute la naturaleza de derecho humano del debido proceso, este es progresivo y evolutivo. En tanto derecho humano, el debido proceso es un instrumento para alcanzar justicia ${ }^{8}$ que comprende a todos, incluida la administración del Estado. Al respecto, la Corte precisó, en su sentencia en el caso Baena Ricardo, que el Estado -la administraciónno está excluido de cumplir con ese deber, acorde con su obligación de respetar y garantizar los derechos humanos a que se refiere el artículo 1.1 de la Convención Americana sobre Derechos Humanos:

“127. Es un derecho humano el obtener todas las garantías que permitan alcanzar decisiones justas, no estando la administración excluida de cumplir con este deber".?

El carácter progresivo del derecho al debido proceso, acorde con su fin de protección del individuo y la realización de la justicia, ha traído consigo la incorporación de nuevos derechos procesales, como el derecho a no incriminarse, el derecho a declarar en presencia de abogado, entre otros. Al respecto, la Corte en su Opinión Consultiva OC-16 sobre el Derecho a la Información sobre la Asistencia Consular en el Marco de las Garantías del Debido Proceso Legal

4 Corte IDH. Caso Blake, sentencia de marzo de 1998, párr. 96. “96. Este Tribunal considera que el artículo 8.1 de la Convención debe interpretarse de manera amplia de modo que dicha interpretación se apoye tanto en el texto literal de esa norma como en su espíritu, y debe ser apreciado de acuerdo con el artículo 29, inciso c) de la Convención, según el cual ninguna disposición de la misma puede interpretarse con exclusión de otros derechos y garantías inherentes al ser humano o que se deriven de la forma democrática representativa de gobierno."

5 Corte IDH. OC-9/87 “Garantías Judiciales en Estados de Emergencia”, 6 de octubre de 1987, párr. 28

6 Corte IDH. Caso Baena Ricardo. Sentencia de 2 de febrero de 2001, párr. 124. "Al respecto, este Tribunal también ha señalado que 'el artículo 8.1 de la Convención debe interpretarse de manera amplia de modo que dicha interpretación se apoye tanto en el texto literal de esa norma como en su espíritu”.

7 Corte IDH. Caso Las Palmeras. Sentencia de 6 de diciembre de 2001. Voto razonado de los jueces Cancado y Pacheco, párr. 16 in fine: “...la discrecionalidad del poder público, en cualquier materia, 'tiene límites infranqueables, siendo uno de ellos el respeto de los derechos humanos' y la 'garantía del debido proceso".

8 Corte IDH. OC 16/99, párr. 117.

9 Corte IDH. Caso Baena Ricardo. Sentencia de 2 de febrero de 2001, párr. 126. 
$(1999)^{10}$ precisó que "[e]l desarrollo histórico del proceso, consecuente con la protección del individuo y la realización de la justicia, ha traído consigo la incorporación de nuevos derechos procesales. Son ejemplo de este carácter evolutivo del proceso los derechos a no autoincriminarse y a declarar en presencia de abogado, que hoy día figuran en la legislación y en la jurisprudencia de los sistemas jurídicos más avanzados. Es así como se ha establecido, en forma progresiva, el aparato de las garantías judiciales que recoge el artículo 14 del Pacto Internacional de Derechos Civiles y Políticos, al que pueden y deben agregarse, bajo el mismo concepto, otras garantías aportadas por diversos instrumentos del Derecho Internacional". ${ }^{11}$

Entre otros derechos conformantes del debido proceso a que se refiere el artículo 8 de la Convención Americana, peticionarios han sostenido ante la Comisión Interamericana de Derechos Humanos -en adelante la Comisión, la Comisión Interamericana, o la CIDH- el derecho a la fundamentación de las resoluciones judiciales. ${ }^{12}$

El carácter evolutivo del debido proceso legal fue señalado por la Corte en su 16a. Opinión Consultiva antes citada, ${ }^{13}$ que, tal como lo señala el juez Cancado, "ha servido de sendero e inspiración para la jurisprudencia internacional in statu nascendi sobre la materia". ${ }^{14}$ Dicha opinión consultiva reconoció, en el contexto de la evolución del Derecho en el tiempo y en función de nuevas necesidades de protección del ser humano, el derecho a la información sobre la asistencia consular contenida en el artículo 36(1) (b) de la Convención de Viena de 1963 sobre Relaciones Consulares en el universo conceptual de los derechos humanos, específicamente de las garantías del debido proceso legal. ${ }^{15}$

Otro ejemplo de la naturaleza evolutiva del derecho al debido proceso es precisado por los jueces Cancado y Pacheco, en su voto razonado conjunto a la sentencia de 6 de diciembre en el caso Las Palmeras, ${ }^{16}$ al precisar que el debido proceso debe ser respetado por cualquier autoridad mediante las resoluciones que determinen derechos y obligaciones de las personas, sean administrativas, legislativas o judiciales:

${ }^{10}$ Corte IDH. Opinión Consultiva n. 16 (del 01.10.1999), Serie A, n. 16, pp. 110-112, párr. 117-122, y cf. pp. 108-109. párr. 113-114.

11 Corte IDH. OC 16/99, párr. 117.

12 Caso de los Magistrados No Ratificados (Perú).

13 Corte IDH, Opinión Consultiva n. 16 (del 01.10.1999), Serie A, n. 16, pp. 110-112, párr. 117-122, y cf. pp. 108-109. párr. 113-114.

14 Véase Corte IDH. Caso Las Palmeras, sentencia de 6 de diciembre de 2001. Voto razonado conjunto de los jueces Cancado y Pacheco, párr. 15.

15 Corte IDH. Opinión Consultiva n. 16 (del 01.10.1999), Serie A, n. 16. Voto razonado del juez Cancado Trindade, párr. 15.

16 Corte IDH. Caso Las Palmeras. Sentencia de 6 de diciembre de 2001. Voto razonado conjunto de los jueces Cancado y Pacheco, párr. 15-16. Véase también Corte IDH, Caso Baena Ricardo y Otros versus Panamá (Fondo, Sentencia del 02.02.2001, Serie C, n. 72, párr. 126; Corte IDH, Caso Ivcher Bronstein versus Perú (Fondo, Sentencia del 06.02.2001), Serie C, n. 74, párr. 102; Caso del Tribunal Constitucional relativo al Perú (Fondo, Sentencia del 31.01.2001), Serie C, n. 71, párr. 69-71. 
16. Esta Corte ha, además, en casos recientes, sostenido que, si bien el artículo 8 de la Convención Americana se titula "Garantías Judiciales", lo cierto es que este supone que cualquier autoridad pública-sea administrativa, legislativa o judicial- debe respetar las garantías establecidas en la Convención, mediante sus resoluciones que determinen derechos y obligaciones de las personas

\section{VALOR PROTEGIDO}

Es la justicia el valor jurídicamente protegido por el debido proceso. ${ }^{17}$

\section{FIN}

El proceso es un medio para asegurar, en la mayor medida posible, la solución justa de una controversia. ${ }^{18}$

\section{CONDICIONES PARA SU EXISTENCIA}

Efecto útil e igualdad procesal.

En opinión de la Corte Interamericana, para que exista "debido proceso legal" es preciso que un justiciable pueda hacer valer sus derechos y defender sus intereses en forma efectiva y en condiciones de igualdad procesal con otros justiciables. ${ }^{19}$

\section{DEBIDO PROCESO}

\section{EL DEBIDO PROCESO COMO DERECHO EXIGIBLE ANTE CUALQUIER ÓRGANO O AUTORIDAD ESTATAL O INSTANCIA PROCESAL}

En la jurisprudencia establecida por la Corte Interamericana de Derechos Humanos, la observancia de las garantías del debido proceso no solo es exigible a los órganos que ejercen "función jurisdiccional en sentido estricto, sino que deben ser respetadas por todo órgano que ejerza funciones de carácter materialmente jurisdiccional, es decir, de conducir un proceso". En este sentido, en el caso del Tribunal Constitucional, la Corte señaló:

"De conformidad con la separación de los poderes públicos que existe en el Estado de Derecho, si bien la función jurisdiccional compete eminentemente al Poder Judicial, otros órganos o autoridades públicas pueden ejercer funciones del mismo tipo (...). Es decir, que cuando la Convención se refiere al derecho de toda persona a ser oída por un 'juez o tribunal competente' para la 'determinación de sus derechos',

\footnotetext{
Corte IDH. Caso Baena Ricardo. Sentencia de 2 de febrero de 2001, párr. 129; Caso del Instituto de Reeducación del Menor, Sentencia de 2 de septiembre de 2004. Voto razonado del juez Cancado Trindade, párr. 26.

18 Corte IDH. OC 16/99, párr. 117.

19 Corte IDH. OC 16/99, párr. 107.
} 
esta expresión se refiere a cualquier autoridad pública, sea administrativa, legislativa o judicial, que a través de sus resoluciones determine derechos y obligaciones de las personas. Por la razón mencionada, esta Corte considera que cualquier órgano del Estado que ejerza funciones de carácter materialmente jurisdiccional tiene la obligación de adoptar resoluciones apegadas a las garantías del debido proceso legal en los términos del artículo 8 de la Convención Americana". ${ }^{20}$

Es decir, el debido proceso debe ser observado en todas las instancias procesales, tal como señaló la Corte en el caso Ivcher Bronstein:

102. Si bien el artículo 8 de la Convención Americana se titula "Garantías Judiciales", su aplicación no se limita a los recursos judiciales en sentido estricto, "sino al conjunto de requisitos que deben observarse en las instancias procesales" a efecto de que las personas puedan defenderse adecuadamente ante cualquier acto emanado del Estado que pueda afectar sus derechos.

La Corte interpretó en el caso Baena Ricardo que estas "instancias procesales" ${ }^{21}$ pueden ser de orden penal, civil, laboral, fiscal o de cualquier otro carácter, administrativo sancionatorio ${ }^{22}$ o jurisdiccional. En tal sentido, dijo: $:^{23}$

"Si bien el artículo 8 de la Convención Americana se titula 'Garantías Judiciales', su aplicación no se limita a los recursos judiciales en sentido estricto, 'sino [al] conjunto de requisitos que deben observarse en las instancias procesales' a efectos de que las personas estén en condiciones de defender adecuadamente sus derechos ante cualquier tipo de acto del Estado que pueda afectarlos. Es decir, cualquier actuación u omisión de los órganos estatales dentro de un proceso, sea administrativo sancionatorio o jurisdiccional, debe respetar el debido proceso legal".

Como puede verse de la jurisprudencia de la Corte Interamericana de Derechos Humanos, el debido proceso legal ha sido exigido en investigaciones policiales, procedimientos laborales, administrativos, entre otros, además del proceso penal.

20 Corte IDH. Caso Tribunal Constitucional. Sentencia de fondo de 31 de enero de 2001, párr. 71.

21 Ibid., párr. 125: "La Corte observa que el elenco de garantías mínimas establecido en el numeral 2 del artículo 8 de la Convención se aplica a los órdenes mencionados en el numeral 1 del mismo artículo, o sea, la determinación de derechos y obligaciones de orden 'civil, laboral, fiscal o de cualquier otro carácter'. Esto revela el amplio alcance del debido proceso; el individuo tiene el derecho al debido proceso entendido en los términos del artículo 8.1 y 8.2, tanto en materia penal como en todos estos otros órdenes".

22 "Las sanciones administrativas son, como las penales, una expresión del poder punitivo del Estado y que tienen, en ocasiones, naturaleza similar a la de estas. Unas y otras implican menoscabo, privación o alteración de los derechos de las personas, como consecuencia de una conducta ilícita”. En: Corte IDH. Caso Baena Ricardo, Sentencia de 2 de febrero de 2001, párr. 106

23 Corte IDH. Caso Baena Ricardo. Sentencia de 2 de febrero de 2001, párr. 124. 


\subsection{Debido proceso en los procedimiento laboral, administrativo y disciplinario}

La administración debe adoptar decisiones justas, para lo cual debe respetar los derechos humanos y las garantías del debido proceso, no pudiendo invocar el orden público para reducir discrecionalmente las garantías de los administrados. Al respecto, la Corte dijo:

"126. En cualquier materia, inclusive en la laboral y la administrativa, la discrecionalidad de la administración tiene límites infranqueables, siendo uno de ellos el respeto de los derechos humanos. Es importante que la actuación de la administración se encuentre regulada, y esta no puede invocar el orden público para reducir discrecionalmente las garantías de los administrados. Por ejemplo, no puede la administración dictar actos administrativos sancionatorios sin otorgar a los sancionados la garantía del debido proceso.

127. Es un derecho humano el obtener todas las garantías que permitan alcanzar decisiones justas, no estando la administración excluida de cumplir con este deber. Las garantías mínimas deben respetarse en el procedimiento administrativo y en cualquier otro procedimiento cuya decisión pueda afectar los derechos de las personas”.

En el caso Baruch Ivcher, que fuera privado de su nacionalidad a través de una resolución directoral dictada por la Dirección General de Migraciones y Naturalización, entidad de carácter administrativo que declaró sin efecto el título de nacionalidad, ${ }^{24}$ la Corte estimó pertinente considerar la aplicación del art. 8 de la $\mathrm{CADH}$ en el contexto del proceso administrativo, es decir, verificar la observancia del debido proceso.

La obligación de observar el debido proceso legal en todas las instancias procesales, incluido el proceso disciplinario, no admite excepciones, tal como lo señaló la Corte en el caso Baena y otros:

“129. La justicia, realizada a través del debido proceso legal, como verdadero valor jurídicamente protegido, se debe garantizar en todo proceso disciplinario, y los Estados no pueden sustraerse de esta obligación argumentando que no se aplican las debidas garantías del artículo 8 de la Convención Americana en el caso de sanciones disciplinarias y no penales. Permitirles a los Estados dicha interpretación equivaldría a dejar a su libre voluntad la aplicación o no del derecho de toda persona a un debido proceso". ${ }^{25}$

24 Corte IDH. Caso Ivcher Bronstein. Sentencia de 6 de febrero de 2001, párr. 101: "101. Como se ha demostrado, la Dirección General de Migraciones y Naturalización, entidad de carácter administrativo, fue la autoridad que dictó la 'resolución directoral' que dejó sin efecto el título de nacionalidad del señor Ivcher Bronstein. Por esta razón, el Tribunal estima pertinente considerar la aplicación del artículo 8 de la Convención Americana a los hechos del presente caso en el contexto del proceso administrativo".

25 Corte IDH. Caso Baena Ricardo. Sentencia de 2 de febrero de 2001, párr. 129. 


\subsection{Debido proceso en procedimiento seguido por empresas del Estado}

En el caso Baena Ricardo y otros, la Corte dijo que "los directores generales y las juntas directivas de las empresas estatales no son jueces o tribunales en un sentido estricto; sin embargo, en el presente caso las decisiones adoptadas por ellos afectaron derechos de los trabajadores, por lo que resultaba indispensable que dichas autoridades cumplieran con lo estipulado en el artículo 8 de la $\mathrm{CADH}^{26}{ }^{26}$

\subsection{Debido proceso en procedimiento seguido a funcionarios del Estado bajo control político}

El Parlamento también está sujeto al respeto de las garantías del debido proceso cuando realice el control parlamentario de otros órganos o poderes del Estado. Por ello, en el ejercicio de tal función política pero de contenido jurisdiccional, el Parlamento no puede actuar de manera arbitraria vulnerando los derechos de los investigados, sino que deberá respetar las garantías del debido proceso, sobre todo si de su actuación se pueda derivar alguna clase de sanción o la afectación de algún derecho. ${ }^{27}$

\section{DERECHO AL DEBIDO PROCESO COMO DERECHO EXIGIBLE POR LOS FAMILIARES DE LAS VÍCTIMAS DIRECTAS}

La Corte Interamericana sostuvo en el caso Blake que una interpretación amplia del debido proceso confiere a los familiares de las víctimas de violaciones de derechos humanos, específicamente de desaparición forzada, el derecho a contar con un proceso contra los responsables de las mismas. Así, afirmó:

“97. Así interpretado, el mencionado artículo 8.1 de la Convención comprende también el derecho de los familiares de la víctima a las garantías judiciales, por cuanto "todo acto de desaparición forzada sustrae a la víctima de la protección de la ley y le causa graves sufrimientos, lo mismo que a su familia" (el subrayado no es del original) (Declaración de Naciones Unidas sobre la Protección de Todas las Personas contra las Desapariciones Forzadas artículo 1.2). En consecuencia, el artículo 8.1 de la Convención Americana confiere a los familiares del señor Nicholas Blake el derecho a que su desaparición y muerte sean efectivamente investigadas por las autoridades de Guatemala; a que se siga un proceso contra los responsables de estos ilícitos; a que en su caso se les impongan las sanciones pertinentes, y a que se indemnicen los

26 Corte IDH. Caso Baena Ricardo. Sentencia de fondo, párr. 130.

27 Corte IDH. Caso Tribunal Constitucional. Sentencia de fondo, párr. 68. 
daños y perjuicios que han sufrido dichos familiares. Por lo tanto, la Corte declara que Guatemala violó el artículo 8.1 de la Convención Americana, en perjuicio de los familiares del señor Nicholas Blake en relación con el artículo 1.1 de la Convención." 28

\subsection{Debido proceso y niños y niñas}

Si nadie puede sustraerse de la obligación de respetar el debido proceso, pues todas las personas tienen ese derecho, que también debe observado cuando se trate de niños o niñas. Sin embargo, cabe preguntarse si las condiciones son las mismas, o debe observarse algunas en especial.

En el caso del Instituto de Reeducación del Menor, la Corte sostuvo que las garantías del artículo 8 de la Convención Americana sobre Derechos Humanos se reconocen a todas las personas por igual, y que tratándose de derechos de los niños y niñas a que se refiere el artículo 19 de la Convención, estas deben observarse "en cualesquiera procesos administrativos o judiciales en los que se discuta algún derecho de un niño", ${ }^{29}$ y señaló lo siguiente:

"Si bien los derechos procesales y sus correlativas garantías son aplicables a todas las personas, en el caso de los niños el ejercicio de aquellos supone, por las condiciones especiales en las que se encuentran los niños, la adopción de ciertas medidas específicas con el propósito de que gocen efectivamente de dichos derechos y garantías." ${ }^{30}$

La Corte entiende que es pertinente “... atender en forma diferenciada y específica las cuestiones referentes a los niños, y particularmente las relacionadas con la conducta ilícita”; 31 en este último caso, a través del establecimiento de órganos jurisdiccionales especializados para el conocimiento de conductas penalmente típicas atribuidas a aquellos y un procedimiento especial por el cual se conozcan estas infracciones a la ley penal, remitiéndose a la Convención sobre los Derechos del Niño, que contempla el "establecimiento de leyes, procedimientos, autoridades e instituciones específicos para los niños de quienes se alegue que han infringido las leyes penales o a quienes se acuse o declare culpables de haber infringido esas leyes". ${ }^{32}$ Esto se sustenta en el reconocimiento del "estado general de vulnerabilidad del niño ante los procedimientos judiciales, así como el impacto mayor que genera al niño el ser sometido a un juicio penal". ${ }^{33}$

28 Corte IDH. Caso Blake. Sentencia de marzo de 1998, párr. 97.

29 Corte IDH. Caso Instituto de Reeducación del Menor. Sentencia de de 2 de septiembre de 2004, párr. 209.

30 Corte IDH. Caso Instituto de Reeducación del Menor. Sentencia de 2 de septiembre de 2004, párr. 209.

31 Corte IDH. Caso Instituto de Reeducación del Menor. Sentencia de 2 de septiembre de 2004, párr. 210.

32 Artículo 40.3 de la Convención sobre los Derechos del Niño.

33 Corte IDH. Caso Instituto de Reeducación del Menor. Sentencia de 2 de septiembre de 2004, párr. 212. 
Para la Corte, la jurisdicción especial para niños debe caracterizarse, inter alia, por los siguientes elementos: 1) en primer lugar, la posibilidad de adoptar medidas para tratar a esos niños sin recurrir a procedimientos judiciales; ${ }^{34} 2$ ) en el caso de que un proceso judicial sea necesario, asesoramiento psicológico para el niño durante el procedimiento, control respecto de la manera de tomar el testimonio del niño y regulación de la publicidad del proceso; 3) margen suficiente para el ejercicio de facultades discrecionales en las diferentes etapas de los juicios y en las distintas fases de la administración de justicia de niños; ${ }^{35}$ y 4) los que ejerzan dichas facultades deberán estar especialmente preparados y capacitados en los derechos humanos del niño y la psicología infantil para evitar cualquier abuso de la discrecionalidad y para asegurar que las medidas ordenadas en cada caso sean idóneas y proporcionales" ${ }^{36}$.

\subsection{Debido proceso y extranjeros}

En una opinión consultiva por los Estados mexicanos sobre "El Derecho a la Información sobre la Asistencia Consular en el Marco de las Garantías del Debido Proceso Legal"37 en relación con las garantías judiciales mínimas y el debido proceso en el marco de la pena de muerte impuesta judicialmente a extranjeros a quienes el Estado receptor no ha informado de su derecho a comunicarse y a solicitar la asistencia de las autoridades consulares del Estado de su nacionalidad.

Como ya había sostenido la Corte, un tratado puede concernir a la protección de los derechos humanos, con independencia de cuál sea su objeto principal; ${ }^{38}$ en esta interesante jurisprudencia de la Corte, esta analizó la Convención de Viena de 1963 sobre Relaciones Consulares, en el sentido de que "dicho tratado pueda concernir a la protección de los derechos fundamentales de la persona en el continente americano". ${ }^{39}$ Las discusiones se centraron en torno al artículo 36 y el artículo 5 de la Convención de Viena sobre Relaciones Consulares, que son analizados conjuntamente. El artículo 36 "consagra el derecho a la libre comunicación, cuyos titulares -como lo revela en forma unívoca el texto- son tanto el funcionario consular como los nacionales del Estado que envía... El derecho de los detenidos extranjeros a la comunicación con funcionarios consulares del Estado que envía es concebido

34 Artículo 40.3.b) de la Convención sobre los Derechos del Niño.

35 Cfr. Regla 6.1 de las Reglas Mínimas de las Naciones Unidas para la Administración de la Justicia de Menores (Reglas de Beijing), adoptadas por la Asamblea General en su resolución 40/33 de 28 de noviembre de 1985. En Caso Instituto de Reeducación del Menor, párr. 211.

36 Cfr. Regla 6.3 de las Reglas Mínimas de las Naciones Unidas para la Administración de la Justicia de Menores (Reglas de Beijing), adoptadas por la Asamblea General en su resolución 40/33 de 28 de noviembre de 1985; y Artículo 40.4 de la Convención sobre los Derechos del Niño. En Caso Instituto de Reeducación del Menor, párr. 211.

37 Corte IDH. OC- 16/99 de 10 de octubre de 1999, "El Derecho a la Información sobre la Asistencia Consular en el Marco de las Garantías del Debido Proceso Legal".

38 Corte IDH OC 1/82. "Otros tratados" objeto de la función consultiva de la Corte (art. 64 Convención Americana sobre Derechos Humanos), de 24 de septiembre de 1982, punto primero.

39 Corte IDH OC-16/99, párr. 76. 
como un derecho del detenido en las más recientes manifestaciones del derecho penal internacional" 40 . Mientras que el artículo 5 refiere que "la función primordial del funcionario consular, el otorgamiento de asistencia al nacional del Estado que envía en la defensa de sus derechos ante las autoridades del Estado receptor".

La Corte estimó que "la norma que consagra la comunicación consular tiene un doble propósito: reconocer el derecho de los Estados de asistir a sus nacionales a través de las actuaciones del funcionario consular y, en forma paralela, reconocer el derecho correlativo de que goza el nacional del Estado que envía para acceder al funcionario consular con el fin de procurar dicha asistencia”. ${ }^{41}$

Tratándose de una persona extranjera privada de libertad, el art. 36.1.b consagra, entre otros, su derecho a ser informada, "sin dilación", de que tiene:

a) derecho a solicitar y obtener que las autoridades competentes del Estado receptor informen a la oficina consular competente sobre su arresto, detención o puesta en prisión preventiva, $\mathrm{y}$

b) derecho a dirigir a la oficina consular competente cualquier comunicación, para que esta le sea transmitida "sin demora". ${ }^{42}$

La característica de estos derechos es que su titular es el individuo, ${ }^{43}$ que se confirma por el hecho de que el ejercicio de este derecho solo está limitado por la voluntad del individuo, que puede oponerse "expresamente" a cualquier intervención del funcionario consular en su auxilio, tal como prescribe el artículo 36.1.c) de la Convención de Viena sobre Relaciones Consulares. Esto reafirma la naturaleza individual de los referidos derechos reconocidos en el artículo 36 de dicha Convención. ${ }^{44}$ La Corte concluyó que "el artículo 36 de la Convención de Viena sobre Relaciones Consulares reconoce al detenido extranjero derechos individuales a los que corresponden los deberes correlativos a cargo del Estado receptor" ${ }^{45}$

40 Corte IDH. OC-16/99, párr. 78. La Corte cita: Rules Governing the detention of persons awaiting trial or appeal before the Tribunal or otherwise detained on the authority of the International Tribunal for the Prosecution of Persons Responsible for Serious Violations of International Humanitarian Law Committed in the Territory of the Former Yugoslavia since 1991; as amended on 17 November 1997; IT/38/REV.7; Regla 65.

${ }^{41}$ Corte IDH. OC 16/99, párr. 80.

${ }^{42}$ Core IDH, OC 16/99, párr. 81

43 Corte IDH. OC 16/99, párr. 82.

${ }^{44}$ Convención de Viena de 1963 sobre Relaciones Consulares. Artículo 36.1, c) los funcionarios consulares tendrán derecho a visitar al nacional del Estado que envía que se halle arrestado, detenido o en prisión preventiva, a conversar con él y a organizar su defensa ante los tribunales. Asimismo, tendrán derecho a visitar a todo nacional del Estado que envía que, en su circunscripción, se halle arrestado, detenido o preso en cumplimiento de una sentencia. Sin embargo, los funcionarios consulares se abstendrán de intervenir en favor del nacional detenido, cuando este se oponga expresamente a ello[;].

45 Corte IDH. OC 16/99, párr. 83. 
Para la Corte, "[s]i el Estado que envía decide brindar su auxilio, en ejercicio de los derechos que le confiere el artículo 36 de la Convención de Viena sobre Relaciones Consulares, podrá asistir al detenido en diversos actos de defensa, como el otorgamiento o contratación de patrocinio letrado, la obtención de pruebas en el país de origen, la verificación de las condiciones en que se ejerce la asistencia legal y la observación de la situación que guarda el procesado mientras se halla en prisión", y concluye que tales conciernen "a la protección de los derechos del nacional del Estado que envía y puede redundar en beneficio de aquel... en particular, en la organización de "su defensa ante los tribunales". ${ }^{46}$

Así, el Estado que lleva a cabo la detención tiene el deber de conocer la identidad de la persona a la que priva de libertad; en consecuencia, determinada su calidad de extranjero, el Estado debe hacer saber -sin dilación- al detenido los derechos que tiene en caso de ser extranjero, del mismo modo en que se le informa sobre los otros derechos reconocidos a quien es privado de libertad; ${ }^{47}$ para atender al propósito de que aquel disponga de una defensa eficaz.

Para ello, la notificación debe ser oportuna, esto es, deberá producirse en el momento procesal adecuado para tal objetivo. La Corte "interpreta que se debe hacer la notificación al momento de privar de la libertad al inculpado, y en todo caso antes de que este rinda su primera declaración ante la autoridad". ${ }^{48}$ Este es un medio para que los inculpados extranjeros puedan hacer pleno uso de otros derechos que la ley reconoce a todas las personas. "Aquellos y estos, indisolublemente vinculados entre sí, forman el conjunto de las garantías procesales y concurren a integrar el debido proceso legal." ${ }^{* 49} \mathrm{La}$ Corte concluye que "el derecho individual -el derecho de los extranjeros detenidos- que se analiza en esta Opinión Consultiva debe ser reconocido y considerado en el marco de las garantías mínimas para brindar a los extranjeros la oportunidad de preparar adecuadamente su defensa y contar con un juicio justo.

\section{ACCESO A LA JURISDICCIÓN}

El artículo 8.1 de la Convención consagra los lineamientos del llamado "debido proceso legal", que consiste en el derecho de toda persona a ser oída con las debidas garantías y dentro de un plazo razonable por un juez o tribunal competente, independiente e imparcial, establecido con anterioridad por la ley, en la sustanciación de cualquier acusación penal formulada en su contra o para la determinación de sus derechos. ${ }^{50}$

46 Corte IDH. OC 16/99, párr. 86-87.

47 Corte IDH. OC-16/99, párr. 96.

48 Corte IDH. OC-16/99, párr. 106

49 Corte IDH. OC 16/99, párr. 120.

50 Corte IDH. Caso Baena Ricardo. Sentencia de 2 de febrero de 2001, párr. 137. 
Un aspecto interesante en relación con la competencia de los órganos judiciales fue introducido por la Corte Interamericana en el caso Caballero Delgado y Santana, cuando señala que al no haber contado el juez con la cooperación de los funcionarios estatales en la investigación se violó el artículo 8.1 de la Convención:

“76. En el expediente existen abundantes constancias que demuestran que ciertas autoridades militares obstaculizaron o bien no colaboraron de manera adecuada con las investigaciones en la Procuraduría y con el juez de primera instancia (supra 68). La situación llegó al extremo de que ese juez tuvo que dirigirse a la señora Presidenta de la República, por carta de 21 de enero de 1992 que obra en autos, para que intercediera ante las autoridades militares a fin de que se le dieran las facilidades necesarias para inspeccionar la Unidad 003, las armas, los vehículos y los controles de armamentos de esa unidad (supra 68). De acuerdo con lo anterior, el juzgador que tuvo a su cargo la instrucción del proceso hasta el momento en que se declaró incompetente, afrontó problemas generados por las autoridades para reunir los elementos de convicción que consideró necesarios para el debido conocimiento de la causa, lo que constituye una violación del artículo 8.1 de la Convención (supra 68)." 51

Esto nos lleva a presumir que la Corte considera la competencia del juez y también los términos de eficacia en el cumplimiento de su labor jurisdiccional.

Del derecho al acceso a la jurisdicción se desprende que los Estados no deben interponer trabas a las personas que acudan a los jueces o tribunales en busca de que sus derechos sean determinados o protegidos. ${ }^{52}$

La Corte IDH en el caso Cantos, ha reconocido que el derecho al acceso a la justicia puede verse limitado por el cumplimiento de determinados requisitos, siempre que no sean excesivos ni desproporcionados, justificados en razonables necesidades propias de la administración de justicia, así como en los fines legítimos de la misma. ${ }^{53}$

La imposición de tasas que dificulten el acceso de las personas a los tribunales, que no estén justificadas por las razonables necesidades de la administración de justicia, debe entenderse como contraria al artículo 8.1 de la Convención. ${ }^{54}$

En el antes citado caso Cantos, la Corte consideró que la aplicación de una tasa aproximada de 83 millones cuatrocientos mil 459, aun cuando se encuentre determinada por la ley,

51 Corte IDH. Caso Caballero Delgado y Santana. Sentencia de 29 de enero de 1997, párr. 76.

52 Corte IDH. Caso Cantos. Sentencia sobre el fondo, párr. 50.

53 Corte IDH. Caso Cantos. Sentencia sobre el fondo, párr. 50.

${ }^{4}$ Corte IDH. Caso Cantos. Sentencia sobre el fondo, párr. 50. 
constituye una "obstrucción al acceso a la justicia, pues no aparece como razonable, aun cuando la mencionada tasa de justicia sea, en términos aritméticos, proporcional al monto de la demanda". La Corte sostiene que al ser el derecho a la justicia no absoluto, puede estar sujeto a algunas limitaciones discrecionales por parte del Estado, pero "lo cierto es que estas deben guardar correspondencia entre el medio empleado y el fin perseguido, y en definitiva no pueden suponer la negación misma de dicho derecho". ${ }^{55}$ Para satisfacer el acceso a la justicia, se requiere que quienes participan en el proceso puedan hacerlo sin el temor de verse obligados a pagar sumas desproporcionadas o excesivas a causa de haber recurrido a los tribunales. ${ }^{56}$

\subsection{El derecho a ser oído por un órgano jurisdiccional}

Todas las personas tienen el derecho de acceder al sistema judicial para que esos órganos llamados a resolver su pretensión la estudien y emitan una resolución motivada conforme a derecho. Impedir este acceso es la forma más extrema de denegar justicia.

En ese sentido, toda persona está facultada para recurrir ante los órganos jurisdiccionales del Estado a fin de obtener la protección de sus derechos o para hacer valer cualquier otra pretensión.

Este derecho se encuentra previsto en el artículo 8.1 de la Convención Americana, cuando se hace referencia al derecho de toda persona a ser oída para la resolución de sus controversias, con las garantías debidas y por un tribunal competente, independiente e imparcial.

\subsection{Alcance del derecho a ser oído}

Para la Corte, el derecho a ser oído en el proceso comprende la búsqueda del esclarecimiento de los hechos y sanción de los responsables, así como el derecho a ser reparado:

“59. Además, la Corte ha manifestado que del artículo 8 de la Convención se desprende que las víctimas de las violaciones de los derechos humanos, o sus familiares, deben contar con amplias posibilidades de ser oídos y actuar en los respectivos procesos, tanto en procura del esclarecimiento de los hechos y del castigo de los responsables, como en busca de una debida reparación." ${ }^{7}$

\subsubsection{Con las debidas garantías}

Las debidas garantías son entendidas como el conjunto de requisitos que deben observarse

55 Corte IDH. Caso Cantos. Sentencia de fondo, párr. 54.

56 Corte IDH. Caso Cantos. Sentencia de fondo, párr. 55.

57 Corte IDH. Caso Las Palmeras. Sentencia de 6 de diciembre de 2001, párr. 59; Caso Durand y Ugarte, párr. 129, y Caso Villagrán Morales y otros, párr. 227. 
en todas las instancias procesales. La Convención específicamente se refiere a la garantía del acceso a la justicia en un plazo razonable, desarrollando expresamente otras en el artículo 8.2, 8.3, 8.4 y 8.5 de la $\mathrm{CADH}$, precisando que las del artículo 8.2 son las garantías mínimas a observarse en el caso de personas inculpadas. Sin embargo, estas son garantías mínimas, lo que significa que existen otras que en situaciones especiales pueden ser comprendidas en este elenco de garantías, como por ejemplo en el caso de procesos en los que se discuta algún derecho de un niño o de un extranjero

En su OC-16/99, párr. 118-119, la Corte ha dicho que los requisitos que deben ser observados en las instancias procesales para que pueda hablarse de verdaderas y propias garantías judiciales ${ }^{58}$ son aquellos que "sirven para proteger, asegurar o hacer valer la titularidad o el ejercicio de un derecho" 59 , y son "condiciones que deben cumplirse para asegurar la adecuada defensa de aquellos cuyos derechos u obligaciones están bajo consideración judicial”. ${ }^{60}$ En tal sentido, "el proceso debe reconocer y resolver los factores de desigualdad real de quienes son llevados ante la justicia. Es así como se atiende el principio de igualdad ante la ley y los tribunales ${ }^{61}$ y la correlativa prohibición de discriminación. La presencia de condiciones de desigualdad real obliga a adoptar medidas de compensación que contribuyan a reducir o eliminar los obstáculos y deficiencias que impidan o reduzcan la defensa eficaz de los propios intereses. Si no existieran esos medios de compensación, ampliamente reconocidos en diversas vertientes del procedimiento, difícilmente se podría decir que quienes se encuentran en condiciones de desventaja disfrutan de un verdadero acceso a la justicia y se benefician de un debido proceso legal en condiciones de igualdad con quienes no afrontan esas desventajas". ${ }^{62}$

\subsubsection{En un plazo razonable}

El artículo 8.1 de la Convención Americana sobre Derechos Humanos señala que toda persona tiene derecho a ser oída con las debidas garantías "dentro de un plazo razonable",

58 Corte IDH. Opinión Consultiva OC-9/87 de 6 de octubre de 1987. Garantías judiciales en estados de emergencia (arts. 27.2, 25 y 8 Convención Americana sobre Derechos Humanos), párr. 27.

59 Corte IDH. Opinión Consultiva OC-8/87 de 30 de enero de 1987. El hábeas corpus bajo suspensión de garantías (arts. 27.2, 25.1 y 7.6 Convención Americana sobre Derechos Humanos), párr. 25.

60 Corte IDH. Opinión Consultiva OC-9/87 de 6 de octubre de 1987. Garantías judiciales en estados de emergencia (arts. 27.2, 25 y 8 Convención Americana sobre Derechos Humanos), párr. 28. Véase también Caso Genie Lacayo. Sentencia de 29 de enero de 1997, párr. 74; Caso Loayza Tamayo, Sentencia de 17 de septiembre de 1997, párr. 62.

${ }_{61}$ Cfr. Declaración Americana, art. II y XVIII; Declaración Universal, arts. 7 y 10; Pacto Internacional de Derechos Civiles y Políticos (supra nota al pie de página 77), arts. 2.1, 3 y 26; Convención para la Eliminación de Todas las Formas de Discriminación Contra la Mujer, arts. 2 y 15; Convención Internacional sobre la Eliminación de Todas las Formas de Discriminación Racial, arts. 2,5 y 7; Carta Africana de Derechos Humanos y de los Pueblos, arts. 2 y 3; Convención Americana, arts. 1, 8.2 y 24; Convenio para la Protección de los Derechos Humanos y de las Libertades Fundamentales, art. 14.

62 Corte IDH. OC 16/99, párr. 118-119. 
derecho exigible en todo tipo de proceso, pues una demora prolongada podría constituir por sí misma en una violación del debido proceso, ${ }^{63}$

"128. El derecho de acceso a la justicia implica que la solución de la controversia se produzca en tiempo razonable ${ }^{64}$; una demora prolongada puede llegar a

constituir, por sí misma, una violación de las garantías judiciales." ${ }^{65}$

La Corte Interamericana de Derechos Humanos ha dejado en claro que el concepto de plazo razonable no resulta de sencilla definición. Para establecer un lapso preciso que constituya el límite entre la duración razonable y la prolongación indebida de un proceso, la Corte en el caso Genie Lacayo ${ }^{66}$ ha señalado, compartiendo el criterio establecido por la Corte Europea de Derechos humanos, que es necesario examinar las circunstancias particulares de cada caso, debiendo tener en cuenta para tal determinación de la razonabilidad del plazo: a) la complejidad del asunto, b) la actividad procesal del interesado, y c) la conducta de las autoridades judiciales:

“77. El artículo 8.1 de la Convención también se refiere al plazo razonable. Este no es un concepto de sencilla definición. Se pueden invocar para precisarlo los elementos que ha señalado la Corte Europea de Derechos Humanos en varios fallos en los cuales se analizó este concepto, pues este artículo de la Convención Americana es equivalente, en lo esencial, al 6 del Convenio Europeo para la Protección de Derechos Humanos y de las Libertades Fundamentales. De acuerdo con la Corte Europea, se deben tomar en cuenta tres elementos para determinar la razonabilidad del plazo en el cual se desarrolla el proceso: a) la complejidad del asunto; b) la actividad procesal del

63 Corte IDH. Caso López Álvarez vs. Honduras. Sentencia de 1 de febrero de 2006, párr. 128. Alfredo López Álvarez, miembro de una comunidad garífuna hondureña, de acuerdo a la Comisión fue: a) privado de su libertad personal a partir del 27 de abril de 1997, fecha en la que fue detenido por posesión y tráfico ilícito de estupefacientes; b) el 7 de noviembre del año 2000, el juez que conocía la causa dictó sentencia condenatoria en contra del señor López Álvarez que fue anulada el 2 de mayo de 2001 por la Corte de Apelaciones de la Ceiba; esta ordenó retrotraer el juicio a la etapa del sumario, y c) el 13 de enero de 2003 el Tribunal de primera instancia dictó nueva sentencia, confirmada por la Corte de Apelaciones de la Ceiba, que absolvió al señor López Álvarez; sin embargo, este permaneció detenido hasta el 26 de agosto de 2003.

64 Cfr. Caso Myrna Mack Chang. Sentencia de 25 de septiembre de 2003. Serie C No. 101, párr. 209; Caso Bulacio. Sentencia de 18 de septiembre de 2003. Serie C No. 100, párr. 114; y Caso Hilaire, Constantine y Benjamin y otros. Sentencia de 21 de junio de 2002. Serie C No. 94, párr. 142 a 145.

${ }^{65}$ Cfr. Caso García Asto y Ramirez Rojas, supra nota 7, párr. 166; Caso Gómez Palomino, supra nota 7, párr. 85; Caso de la Comunidad Moiwana. Sentencia de 15 de junio de 2005. Serie C No. 124, párr. 160.

66 Corte IDH. Caso Genie Lacayo. Sentencia de 29 de enero de 1997, párr. 77-81. Cfr. Caso de las Hermanas Serrano Cruz, supra nota 2, párr. 67; Caso Tibi, supra nota 6, párr. 175; y Caso Ricardo Canese. Sentencia de 31 de agosto de 2004. Serie C No. 111, párr. 141. Véase también Caso Acosta Calderón. Sentencia de 24 de junio de 2005, párr. 105: "Para examinar la razonabilidad de este proceso según los términos del artículo 8.1 de la Convención, la Corte toma en cuenta tres elementos: a) la complejidad del asunto, b) la actividad procesal del interesado y c) la conducta de las autoridades judiciales. Ver también Caso García Asto y Ramírez Rojas, párr. 166; Caso Acosta Calderón, párr. 105, y Caso de las Hermanas Serrano Cruz, párr. 67; Caso López Álvarez, párr. 132. 
interesado; y c) la conducta de las autoridades judiciales (ver, entre otros, Eur. Court H.R., Motta judgment of 19 February 1991, Series A no. 195-A, párr. 30; Eur. Court H.R., Ruiz Mateos v. Spain judgment of 23 June 1993, Series A No. 262, párr. 30)."

La complejidad del asunto es determinada en cada caso, y puede ser apreciada a partir de la extensión de las investigaciones y la amplitud de las pruebas:

"78. Por lo que respecta al primer elemento, es claro que el asunto que se examina es bastante complejo, ya que dada la gran repercusión de la muerte del joven Genie Lacayo, las investigaciones fueron muy extensas y las pruebas muy amplias (supra 69). Todo ello podría justificar que el proceso respectivo, que adicionalmente ha tenido muchos incidentes e instancias, se haya prolongado más que otros de características distintas."

En el caso Acosta Calderón, la Corte dio algunos criterios para la determinación de la complejidad del caso, que en todo requiere pluralidad de sujetos procesales:

"106. El caso no era complejo. No existió pluralidad de sujetos procesales. No aparece del expediente que el señor Acosta Calderón realizara diligencias que retrasaran la causa. De las pruebas en este caso se refleja que la demora de más de cinco años en la tramitación del proceso se debió a la conducta de la autoridad judicial. El expediente incluía documentos que nada tenían que ver con el proceso, lo que demuestra falta de cuidado. Al parecer, la declaración del señor Acosta Calderón, si es que la hubo, se extravió y se tomó dos años después del auto cabeza de proceso de 15 de noviembre de 1989. Lo que es más grave, el trámite de comprobar si la sustancia que condujo a la detención y procesamiento del señor Acosta Calderón era o no una sustancia controlada, indispensable para que se configurara el delito, no se realizó nunca, a pesar de que el Juez lo ordenó por primera vez el 29 de noviembre de 1989, porque la sustancia no fue encontrada por la autoridad pertinente (supra párr. 50.7 y 50.36)."

En el caso López Álvarez, la Corte dijo: ${ }^{67}$

"133. El caso no revestía complejidad especial. Solo había dos encausados (supra párr. 54.32). Se disponía de la sustancia cuya identificación determinaría la pertinencia del enjuiciamiento."

Del mismo modo, la determinación del plazo razonable toma en cuenta la actividad procesal de los interesados, la que no debe ser incompatible con los fines de la justicia o estar dirigida a entorpecer la tramitación del proceso: ${ }^{68}$

67 Corte IDH. Caso López Álvarez, párr. 133.

68 Corte IDH. Caso Genie Lacayo, párr. 79. Véase también Corte IDH. Caso López Álvarez, párr. 133: “...No aparece en el expediente que el señor López Álvarez realizara diligencias que retrasaran o entorpecieran la tramitación de la causa.” 
“79. En cuanto al segundo elemento que se refiere a la actividad procesal del afectado, no consta en autos que el señor Raymond Genie Peñalba, padre de la víctima, hubiere tenido una conducta incompatible con su carácter de acusador privado ni entorpecido la tramitación, pues se limitó a interponer los medios de impugnación reconocidos por la legislación de Nicaragua (supra 70).”

Un elemento importante para la determinación de la responsabilidad del Estado en cuanto a la inobservancia del plazo razonable es la conducta de las autoridades judiciales en las diversas etapas del proceso:

"80. En lo que al tercer elemento se refiere, es decir, en cuanto a la conducta de las autoridades judiciales de Nicaragua, esta Corte estima que no se han producido dilaciones excesivas en las diversas etapas del proceso, con excepción de la última fase todavía pendiente (supra 71), es decir, del recurso de casación ante la Corte Suprema de Justicia interpuesto por la parte acusadora el 29 de agosto de 1994, admitido por dicho Tribunal el 31 siguiente y que, no obstante las diversas solicitudes de las partes, todavía no ha sido resuelto. Incluso considerando la complejidad del asunto, así como las excusas, impedimentos y sustitución de los magistrados de la Corte Suprema de Justicia, el plazo de más de dos años que ha transcurrido desde la admisión del citado recurso de casación no es razonable y por consiguiente este Tribunal debe considerarlo violatorio del artículo 8.1 de la Convención. Lo hará en la parte resolutiva en relación con el artículo 1.1 de la misma, que es el que contiene la obligación general de respetar la Convención.

81. Adicionalmente al estudio de las eventuales demoras en las diversas etapas del proceso, la Corte Europea ha empleado para determinar la razonabilidad del plazo en el conjunto de su trámite lo que llama "análisis global del procedimiento" (Motta, supra 77, párr. 24; Eur. Court H.R., Vernillo judgment of 20 February 1991, Series A No. 198 y Eur. Court H.R., Unión Alimentaria Sanders S.A. judgment of 7 July 1989, Series A, No. 157). Aun cuando se excluyan la investigación policial y el plazo que empleó la Procuraduría General de la República de Nicaragua para formular acusación ante el juez de primera instancia, es decir, realizando el cómputo a partir del 23 de julio de 1991, fecha en que ese juez dictó el auto de apertura del proceso, hasta la actualidad en que todavía no se ha pronunciado sentencia firme, han transcurrido más de cinco años en este proceso, lapso que esta Corte considera que rebasa los límites de la razonabilidad prevista por el artículo 8.1 de la Convención." 
La falta de diligencia así como la inobservancia del debido proceso en el caso López Álvarez fueron señaladas por la Corte en el caso López Álvarez: ${ }^{69}$

“134. Por otro lado, en el proceso penal se dictaron por lo menos cuatro nulidades debido a diversas irregularidades procesales: una parcial, el día 25 de julio de 1997, y tres absolutas los días 9 de septiembre de 1998, 10 de marzo de 1999 y 2 de mayo de 2001 (supra párr. 54.23, 54.28, 54.30 y 54.33).

135. Las nulidades, que sirvieron al propósito de adecuar los procedimientos al debido proceso fueron motivadas por la falta de diligencia en la actuación de las autoridades judiciales que conducían la causa. El juez interno, al realizar las actuaciones posteriormente anuladas, incumplió el deber de dirigir el proceso conforme a derecho. Esto determinó que la presunta víctima fuese obligada a esperar más de seis años para que el Estado administrara justicia.

136. Con fundamento en las consideraciones precedentes y en el estudio global del proceso penal seguido al señor Alfredo López Álvarez, se advierte que este se extendió por más de seis años. El Estado no observó el principio del plazo razonable consagrado en la Convención Americana, por responsabilidad exclusiva de las autoridades judiciales a quienes competía haber administrado justicia.”

Asimismo, la Corte Interamericana ha considerado importante tomar otro criterio desarrollado por la Corte Europea para determinar la razonabilidad del plazo de duración de un proceso: el análisis global del procedimiento.

La Corte, en consecuencia, no opta por precisar un plazo determinado en días calendarios o naturales como el máximo de duración aplicable a un proceso sino que brinda unos criterios a ser evaluados por la judicatura para precisar si se afecta o no el derecho a la duración de un proceso en un plazo razonable, según las características de cada caso.

Así, en el Caso Suárez Rosero, la víctima, la Corte precisó que todo el procedimiento, incluyendo los recursos de instancia, duró más de 50 meses, lo que según la Corte excedió el plazo razonable para ser juzgado:

“70. El principio de "plazo razonable" al que hacen referencia los artículos 7.5 y 8.1 de la Convención Americana tiene como finalidad impedir que los acusados permanezcan largo tiempo bajo acusación y asegurar que esta se decida prontamente.

69 Corte IDH. Caso López Álvarez, párr. 134-136. 
En el presente caso, el primer acto del procedimiento lo constituye la aprehensión del señor Suárez Rosero el 23 de junio de 1992, y, por lo tanto, a partir de ese momento debe comenzar a apreciarse el plazo.

71. Considera la Corte que el proceso termina cuando se dicta sentencia definitiva y firme en el asunto, con lo cual se agota la jurisdicción (cf. Cour Eur. D.H., arrêt Guincho du 10 juillet 1984, serie A No. 81, párr. 29), y que, particularmente en materia penal, dicho plazo debe comprender todo el procedimiento, incluyendo los recursos de instancia que pudieran eventualmente presentarse. Con base en la prueba que consta en el expediente ante la Corte, esta estima que la fecha de conclusión del proceso contra el señor Suárez Rosero en la jurisdicción ecuatoriana fue el 9 de septiembre de 1996, cuando el Presidente de la Corte Superior de Justicia de Quito dictó sentencia condenatoria. Si bien en la audiencia pública el señor Suárez Rosero mencionó la interposición de un recurso contra dicha sentencia, no fue demostrada esa afirmación.

\section{(...)}

73. Con fundamento en las consideraciones precedentes, al realizar un estudio global del procedimiento en la jurisdicción interna contra el señor Suárez Rosero, la Corte advierte que dicho procedimiento duró más de 50 meses. En opinión de la Corte, este período excede en mucho el principio de plazo razonable consagrado en la Convención Americana.

74. Asimismo, la Corte estima que el hecho de que un tribunal ecuatoriano haya declarado culpable al señor Suárez Rosero del delito de encubrimiento no justifica que hubiese sido privado de libertad por más de tres años y diez meses, cuando la ley ecuatoriana establecía un máximo de dos años como pena para ese delito.

75. Por lo anteriormente expresado, la Corte declara que el Estado del Ecuador violó en perjuicio del señor Rafael Iván Suárez Rosero el derecho establecido en los artículos 7.5 y 8.1 de la Convención Americana a ser juzgado dentro de un plazo razonable o ser puesto en libertad." ${ }^{\prime 70}$

En el caso Las Palmeras, la Corte, con relación al proceso de investigación de los hechos, se refirió al plazo razonable, computando a partir de los hechos el inicio del trámite procesal y estableciendo un criterio de un período de cinco años como límite de la razonabilidad. ${ }^{71}$ En este caso, la Corte efectuó el cómputo de cinco años a partir del auto de apertura del proceso penal.

70 CorteIDH. Caso Suárez Rosero. Sentencia de 12 de noviembre de 1997, párr. 70-75.

71 Corte IDH. Caso Las Palmeras, sentencia de 6 de diciembre de 2001, párr. 62-63. 
"62. En lo que atañe al plazo del proceso penal, es importante indicar que el artículo 8.1 de la Convención también se refiere al plazo razonable. En el presente caso $[. .$.$] esta Corte se remite a lo establecido en su sentencia sobre excepciones$ preliminares dictada el 4 de febrero de 2000, en la cual indicó que

'El Estado no ha dado ninguna explicación satisfactoria acerca del trámite procesal desarrollado entre esa fecha y el inicio de 1998. El silencio del Estado debe ser apreciado tomando en cuenta que durante los siete primeros años el trámite procesal no pasó de la etapa indagatoria. Colombia ha mencionado los avances que ocurrieron desde que la Unidad de Derechos Humanos de la Fiscalía General de la Nación tomó a su cargo esta causa. Pero el tema en cuestión no es lo que sucedió en 1998, sino en los primeros siete años a partir de los hechos. Este tiempo es más que suficiente para que un tribunal dicte sentencia. ${ }^{72}$

63. La Corte ha establecido el criterio de que un período de cinco años transcurrido desde el momento del auto de apertura del proceso rebasaba los límites de la razonabilidad. ${ }^{73}$ Dicho criterio se aplica al presente caso.

64. Con fundamento en las consideraciones precedentes, es importante señalar que al hacer el estudio global del procedimiento en la jurisdicción penal interna, el cómputo del plazo desde el 29 de enero de 1991 -fecha en que se dictó el auto de apertura del proceso penal militar- hasta el 25 de marzo de 1998 -cuando se trasladó la causa a la jurisdicción penal ordinaria- y luego desde el día 14 de mayo de 1998, cuando se dictó el auto de avocamiento del proceso por parte del Fiscal Regional de la Unidad Nacional de Derechos Humanos de la Fiscalía General de la Nación, hasta la actualidad, en que todavía no se ha pronunciado una sentencia condenatoria, este Tribunal advierte que, en conjunto, el proceso penal ha durado más diez años, por lo que este período excede los límites de razonabilidad previstos en el artículo 8.1 de la Convención." ${ }^{74}$

En el caso Acosta Calderón ${ }^{75}$-la víctima-, la Corte precisó que la razonabilidad del plazo se debe apreciar en relación con la duración total del proceso, es decir, desde el primer acto procesal hasta que se dicte sentencia definitiva, incluyendo los recursos de instancia que pudieran eventualmente presentarse. Específicamente, en materia penal, la Corte precisa que ese primer acto procesal comienza con la aprehensión del individuo.

72 Corte IDH. Caso Las Palmeras. Excepciones Preliminares, párr. 38.

73 Cfr. Caso Genie Lacayo. Sentencia de 29 de enero de 1997. Serie C No. 30, párr. 81.

74 Cfr. Caso Paniagua Morales y otros, supra nota 8, párr. 152; y Caso Suárez Rosero, supra nota 10, párr. 73.

75 Corte IDH. Caso Acosta Calderón. Sentencia de fondo, párr. 105. 
"104. La razonabilidad del plazo al que se refiere ese precepto se debe apreciar en relación con la duración total del proceso, desde el primer acto procesal hasta que se dicte sentencia definitiva, incluyendo los recursos de instancia que pudieran eventualmente presentarse. ${ }^{76}$ La Corte se ha pronunciado en el sentido de que, en materia penal, el plazo comienza en la fecha de la aprehensión del individuo. ${ }^{77} \mathrm{La}$ aprehensión del señor Acosta Calderón ocurrió el 15 de noviembre de 1989. Por lo tanto, se debe apreciar el plazo a partir de ese momento. El señor Acosta Calderón fue condenado el 8 de diciembre de $1994 \ldots$

105. Para examinar la razonabilidad de este proceso según los términos del artículo 8.1 de la Convención, la Corte toma en cuenta tres elementos: a) la complejidad del asunto, b) la actividad procesal del interesado y c) la conducta de las autoridades judiciales. $^{78}$

106. El caso no era complejo. No existió pluralidad de sujetos procesales. No aparece del expediente que el señor Acosta Calderón realizara diligencias que retrasaran la causa. De las pruebas en este caso se refleja que la demora de más de cinco años en la tramitación del proceso se debió a la conducta de la autoridad judicial. El expediente incluía documentos que nada tenían que ver con el proceso, lo que demuestra falta de cuidado. Al parecer, la declaración del señor Acosta Calderón, si es que la hubo, se extravió y se tomó dos años después del auto cabeza de proceso de 15 de noviembre de 1989. Lo que es más grave, el trámite de comprobar si la sustancia que condujo a la detención y procesamiento del señor Acosta Calderón era o no una sustancia controlada, indispensable para que se configurara el delito, no se realizó nunca, a pesar de que el Juez lo ordenó por primera vez el 29 de noviembre de 1989, porque la sustancia no fue encontrada por la autoridad pertinente (supra párr. 50.7 y 50.36).

107. Asimismo, cabe destacar que un proceso penal, de conformidad con lo que disponía el Código de Procedimiento Penal de 1983, el cual era aplicable a la presunta víctima, no debía exceder de cien días. Sin embargo, en el caso del señor Acosta Calderón, se extendió por más de cinco años sin que existieran razones que pudieran justificar tal demora.

76 Cfr. Caso Tibi, supra nota 6, párr. 168; y Caso Suárez Rosero, supra nota 60, párr. 70.

77 Cfr. Caso Tibi, supra nota 6, párr. 168; Caso Suárez Rosero, supra nota 60, párr. 70; y en igual sentido, Hennig v. Austria, No. 41444/98, párr. 32, ECHR 2003-I; y Reinhardt and Slimane-Kaid v. France, 23043/93, párr. 93, ECHR 1998-II.

78 Cfr. Caso de las Hermanas Serrano Cruz, supra nota 2, párr. 67; Caso Tibi, supra nota 6, párr. 175; y Caso Ricardo Canese. Sentencia de 31 de agosto de 2004. Serie C No. 111, párr. 141. 
108. Por todo lo anterior, la Corte concluye que el Estado violó, en perjuicio del señor Acosta Calderón, el derecho a ser juzgado dentro de un plazo razonable, que establece el artículo 8.1 de la Convención Americana."

Este criterio ha sido reafirmado por la Corte en su sentencia en el caso López Álvarez en su sentencia de enero de $2006:^{79}$

“129. El plazo razonable al que se refiere el artículo 8.1 de la Convención se debe apreciar en relación con la duración total del procedimiento penal que se desarrolla en contra de cierto imputado, hasta que se dicta sentencia definitiva. ${ }^{80}$ En materia penal este plazo comienza cuando se presenta el primer acto de procedimiento dirigido en contra de determinada persona como probable responsable de cierto delito."

En el caso Paniagua Morales (8 de marzo de 1998), los procedimientos de investigación de violaciones a los derechos humanos ocurridos en 1977 no contaban con una decisión final a la fecha de decisión de la Corte, por lo que esta consideró que excedía el plazo razonable. Habían transcurrido aproximadamente 21 años.

\subsection{Derecho a un tribunal competente, independiente e imparcial}

El juez encargado del conocimiento de una causa debe ser competente, independiente e imparcial. ${ }^{81}$ El artículo 8.1 de la Convención Americana sobre Derechos Humanos establece que toda persona tiene derecho a ser oída, en cualquier proceso, por un "tribunal competente, independiente e imparcial". El cumplimiento de estos tres requisitos permite garantizar la correcta determinación de los derechos y obligaciones de las personas. Tales características, además, deben estar presentes en todos los órganos del Estado que ejercen función jurisdiccional, según lo ha establecido la Corte Interamericana de Derechos Humanos.

No se garantizan los requisitos de independencia, competencia e imparcialidad si quienes toman parte en el combate son los encargados de juzgar a sus pares por la ejecución de civiles; en consecuencia, se afecta el acceso a la justicia:

9 Corte IDH. Caso López Álvarez vs. Honduras. Sentencia de 1 de febrero de 2006, párr. 129.

80 Cfr. Caso Acosta Calderón, supra nota 18, párr. 104; Caso Tibi, supra nota 80, párr. 168, y Caso Suárez Rosero, supra nota 87, párr. 70.

81 Corte IDH. Caso Las Palmeras, Sentencia de 6 de diciembre de 2001, párr. 53: "Como se ha dicho con anterioridad, el juez encargado del conocimiento de una causa debe ser competente, independiente e imparcial..."; Caso Ivcher Bronstein, Sentencia de 6 de febrero de 2001, párr. 112; Caso Castillo Petruzzi y otros, Sentencia de 30 de mayo de 1999, párr. 130; Caso 19 Comerciantes, Sentencia de 5 de julio de 2004, párr. 167. 
"53. Como se ha dicho con anterioridad, el juez encargado del conocimiento de una causa debe ser competente, independiente e imparcial. ${ }^{82}$ En el caso sub judice, las propias fuerzas armadas involucradas en el combate contra las grupos insurgentes son los encargados de juzgar a sus mismos pares por la ejecución de civiles, tal y como lo ha reconocido el propio Estado. En consecuencia, la investigación y sanción de los responsables debió recaer, desde un principio, en la justicia ordinaria, independientemente de que los supuestos autores hayan sido policías en servicio activo. Pese a lo anterior, el Estado dispuso que la justicia militar fuera la encargada de la investigación de los hechos acaecidos en Las Palmeras, la cual llevó adelante dicha investigación durante más de 7 años -hasta el traslado de la causa a la justicia ordinaria- sin obtener resultados positivos respecto de la individualización y condena de los responsables.

54. En conclusión, la aplicación de la jurisdicción militar en este caso no garantizó el debido proceso en los términos del artículo 8.1 de la Convención Americana, que regula el derecho de acceso a la justicia de los familiares de las víctimas del caso."

Los errores cometidos por un juez o tribunal competente, independiente e imparcial, respecto a la aplicación o interpretación de la ley, o la apreciación o valoración de pruebas, no acarrean la nulidad del proceso ni de la sentencia. ${ }^{83}$

\subsubsection{Tribunal competente}

Se considera tribunal competente a aquel que de acuerdo a determinadas reglas previamente establecidas (territorio, materia, etc.) es el llamado para conocer y resolver una controversia. También conocido como el derecho a un juez natural, esta garantía presenta dos alcances: por un lado, la imposibilidad de ser sometido a un proceso ante la autoridad de quien no es juez o que carece de competencia para resolver una determinada controversia; y por otro, que la competencia de los jueces y tribunales se encuentre previamente establecida por la ley.

En el caso Castillo Petruzzi, la Corte señaló que hubo numerosas violaciones, desde la investigación policial hasta el período de conocimiento de los tribunales militares. La Corte afirmó que, "En efecto el proceso se siguió ante un órgano jurisdiccional que no puede ser considerado "juez natural". ${ }^{84}$

82 Caso Ivcher Bronstein, Sentencia de 6 de febrero de 2001, Serie C No. 74, párr. 112, y Caso Castillo Petruzzi y Otros, supra nota 6, párr. 130 .

83 Corte IDH. Caso Castillo Petruzzi, Sentencia de fondo, párr. 220.

84 Corte IDH. Caso Castillo Petruzzi. Sentencia de fondo, párr. 221. 
Sobre el Caso Cesti Hurtado, la Corte afirmó que el proceso seguido contra el señor Cesti en el fuero militar fue irregular, porque dicho fuero era incompetente para procesarlo. A esa fecha el señor Cesti tenía el carácter de militar en retiro y "por ello no podía ser juzgado por los tribunales militares. En consecuencia, el juicio al cual fue sometido el señor Cesti Hurtado constituye una violación al derecho a ser oído por un tribunal competente, de acuerdo con el artículo 8.1 de la Convención". ${ }^{85}$

\subsubsection{Justicia militar}

En principio, la Corte Interamericana de Derechos Humanos no considera contraria a la Convención Americana la existencia de estos tribunales, pero estima necesario tomar en cuenta determinados criterios para su regulación a nivel interno, especialmente en lo que se refiere a la necesidad de dejar fuera de su competencia el juzgamiento de civiles. Así, en el Caso Genie Lacayo precisó que la actuación de una jurisdicción militar no significa que per se se violen los derechos humanos:

"84. Esta conformidad debe analizarse exclusivamente en relación con los derechos procesales del señor Raymond Genie Peñalba que es el afectado en este asunto, pero no respecto de los acusados en el proceso correspondiente, lo que no está bajo consideración de esta Corte ya que la circunstancia de que se trate de una jurisdicción militar no significa per se que se violen los derechos humanos que la Convención garantiza a la parte acusadora.

85. De los elementos de convicción que se han rendido en este asunto, se desprende que el señor Raymond Genie Peñalba pudo intervenir en el procedimiento militar, ofrecer pruebas, ejercitar los recursos respectivos y finalmente acudir en casación ante la Corte Suprema de Justicia de Nicaragua, a la que corresponde pronunciarse sobre el fondo de la controversia criminal y determinar, en su caso, la existencia de violaciones procesales concretas. Por tanto, respecto del afectado no puede afirmarse que la aplicación de los decretos sobre enjuiciamiento militar hubiese restringido sus derechos procesales protegidos por la Convención (supra 72).

88. Según esta Corte, no se ha demostrado que el señor Raymond Genie Peñalba, al comparecer como parte acusadora ante los tribunales castrenses, se hubiese encontrado en clara situación de inferioridad con respecto de los acusados o de los jueces militares y, por consiguiente, no se ha infringido el derecho de igualdad ante la ley establecido por el artículo 24 de la Convención, invocado por la Comisión

85 Corte IDH. Caso Cesti Hurtado. Sentencia de fondo, párr. 151, 194. 
Interamericana, en virtud de que este derecho solo puede examinarse en este caso en relación con los derechos procesales del afectado (supra 72).”

En el caso Las Palmeras, la Corte recordó que la jurisdicción militar "se establece por diversas legislaciones con el fin de mantener el orden y la disciplina dentro de las fuerzas armadas. Inclusive, esta jurisdicción funcional reserva su aplicación a los militares que hayan incurrido en delito o falta dentro del ejercicio de sus funciones y bajo ciertas circunstancias" ${ }^{86}$

Pero, "[c]uando la justicia militar asume competencia sobre un asunto que debe conocer la justicia ordinaria, se ve afectado el derecho al juez natural y, a fortiori, el debido proceso", el cual, a su vez, se encuentra íntimamente ligado al propio derecho de acceso a la justicia. ${ }^{87}$

Actuación Ultra vires de tribunales militares.

“61. En primer término, al aplicar los Decretos-Leyes No 25.659 (delito de traición a la patria) y No 25.475 (delito de terrorismo) expedidos por el Estado, la jurisdicción militar del Perú violó el artículo 8.1 de la Convención, en lo que concierne a la exigencia de juez competente. En efecto, al dictar sentencia firme absolutoria por el delito de traición a la patria del cual fue acusada la señora María Elena Loayza Tamayo, la jurisdicción militar carecía de competencia para mantenerla en detención y menos aún para declarar, en el fallo absolutorio de última instancia, que "existiendo evidencia de la comisión del delito de terrorismo dispone remitir los actuados pertinentes al Fuero Común y poner a disposición de la Autoridad competente a la referida denunciada”. Con esta conducta, los tribunales castrenses actuando ultra vires usurparon jurisdicción e invadieron facultades de los organismos judiciales ordinarios, ya que según el mencionado Decreto-Ley No 25.475 (delito de terrorismo), correspondía a la Policía Nacional y al Ministerio Público la investigación de ese ilícito y a los jueces ordinarios el conocimiento del mismo. Por otra parte, dichas autoridades judiciales comunes eran las únicas que tenían la facultad de ordenar la detención y decretar la prisión preventiva de los acusados. Como se desprende de lo anterior, los referidos Decretos-Leyes No 25.659 (delito de traición a la patria) y No 25.475 (delito de terrorismo) dividieron la competencia entre los tribunales castrenses y los ordinarios y atribuyeron el conocimiento del delito de traición a la patria a los primeros y el de terrorismo a los segundos." 88

Jurisdicción Militar y Estado democrático de derecho.

86 Caso Las Palmeras, Sentencia de 6 de diciembre de 2001, párr. 52; Caso Cantoral Benavides, párr. 112 y Caso Castillo Petruzzi y Otros. Sentencia de 30 de mayo de 1999, párr. 128.

87 Corte IDH. Caso Las Palmeras, Sentencia de 6 de diciembre de 2001, párr. 52; Caso Cantoral Benavides, Sentencia de 18 de agosto de 2000, párr. 112; Caso Castillo Petruzzi y otros. Sentencia de 30 de mayo de 1999, párr. 128; Caso 19 Comerciantes, Sentencia de 5 de julio de 2005, párr. 167.

88 Corte IDH. Caso Loayza Tamayo. Sentencia de 17 de septiembre de 1997, párr. 61. 
Para la Corte, "en un Estado democrático de derecho, la jurisdicción penal militar ha de tener un alcance restrictivo y excepcional y estar encaminada a la protección de intereses jurídicos especiales, vinculados con las funciones que la ley asigna a las fuerzas militares. Por ello, solo se debe juzgar a militares por la comisión de delitos o faltas que por su propia naturaleza atenten contra bienes jurídicos propios del orden militar" ${ }^{89}$ De forma tal que su competencia está restringida al conocimiento de las conductas de los miembros de la fuerza pública que tengan una relación directa con una tarea militar o policial legítima. ${ }^{90}$

Cuando se trate de miembros retirados del Ejército, a quienes se les imputa “... acciones... expresiones indirectas de las funciones específicas del cargo que desempeñaban[...]”, sobre la base que existe una evidente “... relación causal con la función militar que desempeñaban” y que “... tal participación delictiva ... tiene relación con la actividad militar..." vínculo entre el hecho delictivo y la actividad relacionada con el servicio se rompe cuando el delito adquiere una gravedad inusitada, tal como ocurre con los llamados delitos de lesa humanidad. En estas circunstancias, el caso debe ser atribuido a la justicia ordinaria, dada la total contradicción entre el delito y los cometidos constitucionales de la Fuerza Pública."92

Debemos mencionar un caso en que la Corte -el caso Loayza Tamayo- no se pronunció respecto a la violación a las garantías de independencia e imparcialidad respecto a los tribunales militares, por cuanto la ausencia de esos requisitos no causó perjuicio a la víctima,

“60. En relación con el argumento de la Comisión de que los tribunales militares que juzgaron a la señora María Elena Loayza Tamayo carecen de independencia e imparcialidad, requisitos exigidos por el artículo 8.1 de la Convención como elementos indispensables del debido proceso, la Corte considera que es innecesario pronunciarse por cuanto la señora María Elena Loayza Tamayo fue absuelta por dicha jurisdicción castrense y, por tanto, la posible ausencia de estos requisitos no le causaron perjuicio jurídico en este aspecto, con independencia de otras violaciones que se examinarán en los párrafos siguientes de este fallo." 93

89 Corte IDH. Caso Las Palmeras. Sentencia de 6 de diciembre de 2001, párr. 51, 51. "Al respecto, el Tribunal ya ha establecido que en un Estado democrático de derecho la jurisdicción penal militar ha de tener un alcance restrictivo y excepcional y estar encaminada a la protección de intereses jurídicos especiales, vinculados con las funciones que la ley asigna a las fuerzas militares. Por ello, solo se debe juzgar a militares por la comisión de delitos o faltas que por su propia naturaleza atenten contra bienes jurídicos propios del orden militar"; Caso Cantoral Benavides, Sentencia de 18 de agosto de 2000, párr. 113, Caso Durand y Ugarte, Sentencia de 16 de agosto de 2002, párr. 117; Caso 19 Comerciantes, Sentencia de 5 de julio de 2004, párr. 165 .

90 Caso 19 Comerciantes. Sentencia de 5 de julio de 2005, 166.

91 Corte IDH. Caso 19 Comerciantes. Sentencia de 5 de julio de 2004, párr. 168.

2 Ibid., párr. 168.

93 Corte IDH. Caso Loayza Tamayo. Sentencia de 17 de septiembre de 1997, párr. 60. 
Sin embargo, sí se pronunció sobre la incompetencia de los tribunales militares por su actuación ultra vires:

"61. En primer término, al aplicar los Decretos-Leyes No 25.659 (delito de traición a la patria) y No 25.475 (delito de terrorismo) expedidos por el Estado, la jurisdicción militar del Perú violó el artículo 8.1 de la Convención, en lo que concierne a la exigencia de juez competente. En efecto, al dictar sentencia firme absolutoria por el delito de traición a la patria del cual fue acusada la señora María Elena Loayza Tamayo, la jurisdicción militar carecía de competencia para mantenerla en detención y menos aún para declarar, en el fallo absolutorio de última instancia, que 'existiendo evidencia de la comisión del delito de terrorismo dispone remitir los actuados pertinentes al Fuero Común y poner a disposición de la Autoridad competente a la referida denunciada'. Con esta conducta, los tribunales castrenses actuando ultra vires usurparon jurisdicción e invadieron facultades de los organismos judiciales ordinarios, ya que según el mencionado Decreto-Ley No 25.475 (delito de terrorismo), correspondía a la Policía Nacional y al Ministerio Público la investigación de ese ilícito y a los jueces ordinarios el conocimiento del mismo. Por otra parte, dichas autoridades judiciales comunes eran las únicas que tenían la facultad de ordenar la detención y decretar la prisión preventiva de los acusados. Como se desprende de lo anterior, los referidos Decretos-Leyes No 25.659 (delito de traición a la patria) y No 25.475 (delito de terrorismo) dividieron la competencia entre los tribunales castrenses y los ordinarios y atribuyeron el conocimiento del delito de traición a la patria a los primeros y el de terrorismo a los segundos." Corte IDH. Caso Loayza Tamayo. Sentencia de 17 de septiembre de 1997, párr. 61

\subsubsection{2 Órganos administrativos}

En el caso Baruch Ivcher, la Corte constató que “... la autoridad que dejó sin efecto el título de nacionalidad del señor Ivcher resultó ser incompetente... como quedó establecido, el señor Ivcher Bronstein adquirió la nacionalidad peruana a través de una resolución suprema del Presidente y su título de nacionalidad fue firmada por el MRE; sin embargo, perdió su nacionalidad como resultado de una "resolución directoral de la Dirección de Migraciones y Naturalización, indudablemente de menor jerarquía que la que le otorgó el derecho correspondiente, y que por eso mismo no podía privar de efectos al acto del superior ...". De lo que resulta que la Dirección de Migraciones era un órgano incompetente. ${ }^{94}$

\subsubsection{Tribunal independiente}

94 Corte IDH. Caso Baruch Ivcher, sentencia de fondo, párr. 95-97. 
La independencia de los tribunales alude al grado de relación que existe entre los magistrados de las diversas instancias del Poder Judicial respecto a los demás órganos del Estado, en especial los de carácter político, como lo son el Ejecutivo o el Legislativo. En este sentido, los jueces se encuentran obligados a dar respuesta a las pretensiones que se les presentan únicamente con arreglo a derecho, sin que existan otros condicionamientos para tal efecto.

De forma tal que, en el ejercicio de la actividad jurisdiccional, ningún juez o tribunal se encuentra sometido a la voluntad de las instancias superiores, debiendo en consecuencia mantener también su independencia respecto a todos los demás órganos judiciales:

“... uno de los objetivos principales que tiene la separación de los poderes públicos es la garantía de la independencia de los jueces y, para tales efectos, los diferentes sistemas políticos han ideado procedimientos estrictos, tanto para su nombramiento como para su destitución... y es necesario que se garantice la independencia de cualquier juez en un Estado de Derecho y, en especial, la del juez constitucional en razón de la naturaleza de los asuntos sometidos a su conocimiento."95

\subsubsection{Tribunal imparcial}

La garantía del tribunal imparcial permite contar con órganos jurisdiccionales que aseguren a las personas que sus controversias serán decididas por un ente que no tiene ningún interés o relación personal con el problema y que mantendrá una posición objetiva al momento de resolverlo. En consecuencia, la imparcialidad de los tribunales implica que las instancias que conozcan cualquier clase de proceso no deben tener opiniones anticipadas sobre la forma en que los conducirán, el resultado de los mismos, compromisos con alguna de las partes, etc. Asimismo, esta garantía obliga al magistrado a no dejarse influenciar por el contenido de las noticias o las reacciones del público sobre sus actuaciones, por información diferente a la que aparece en el proceso, ni por influencias, alicientes, presiones, amenazas o intromisiones indebidas de cualquier sector.

\section{GARANTÍAS MÍNIMAS}

Un procedimiento en el que están sensiblemente restringidos los derechos fundamentales que integran el debido proceso: presunción de inocencia, principio de contradicción de pruebas, restricciones a la comunicación entre la defensa y el procesado, entre otros, no alcanza los estándares de un juicio justo.

95 Corte IDH. Caso Tribunal Constitucional (Aguirre Roca, Rey Terry, Revoredo Marsano vs. Perú). Sentencia de 31 de enero de 2001, párr. 73 y 75. 
"62. En segundo término, la señora María Elena Loayza Tamayo fue enjuiciada y condenada por un procedimiento excepcional en el que, obviamente, están sensiblemente restringidos los derechos fundamentales que integran el debido proceso. Estos procesos no alcanzan los estándares de un juicio justo ya que no se reconoce la presunción de inocencia; se prohíbe a los procesados contradecir las pruebas y ejercer el control de las mismas; se limita la facultad del defensor al impedir que este pueda libremente comunicarse con su defendido e intervenir con pleno conocimiento en todas las etapas del proceso. El hecho de que la señora María Elena Loayza Tamayo haya sido condenada en el fuero ordinario con fundamento en pruebas supuestamente obtenidas en el procedimiento militar, no obstante ser este incompetente, tuvo consecuencias negativas en su contra en el fuero común." Corte IDH. Caso Loayza Tamayo. Sentencia de 17 de septiembre de 1997, párr. 62.

"82. Los incisos c, d y e del artículo 8.2 de la Convención Americana establecen como garantías mínimas, en plena igualdad, de toda persona:

'... [la] concesión al inculpado del tiempo y de los medios adecuados para la preparación de su defensa;

[el] derecho del inculpado de defenderse personalmente o de ser asistido por un defensor de su elección y de comunicarse libre y privadamente con su defensor;

[y el] derecho irrenunciable de ser asistido por un defensor proporcionado por el Estado, remunerado o no según la legislación interna, si el inculpado no se defendiere por sí mismo ni nombrare defensor dentro del plazo establecido por la ley[.]'

83. Debido a su incomunicación durante los primeros 36 días de su detención, el señor Suárez Rosero no tuvo la posibilidad de preparar debidamente su defensa, ya que no pudo contar con el patrocinio letrado de un defensor público y, una vez que pudo obtener un abogado de su elección, no tuvo posibilidad de comunicarse en forma libre y privada con él. Por ende, la Corte considera que el Ecuador violó el artículo 8.2.c, 8.2.d y 8.2.e de la Convención Americana." Corte IDH: Caso Suárez Rosero. Sentencia de 12 de noviembre de 1997, párr. 82-83.

\subsection{La presunción de inocencia}

El artículo 8.2 de la Convención Americana establece que "toda persona inculpada de delito tiene derecho a que se presuma su inocencia mientras no se establezca legalmente su culpabilidad". 
En cuanto a su contenido, la Corte Interamericana de Derechos Humanos ha precisado que "el principio de la presunción de inocencia, tal y como se desprende del artículo 8.2 de la Convención, exige que una persona no pueda ser condenada mientras no exista prueba plena de su responsabilidad penal. Si obra contra ella prueba incompleta o insuficiente, no es procedente condenarla, sino absolverla".

Para la Corte, también se viola el principio de presunción de inocencia cuando un órgano jurisdiccional incompetente atribuye a una persona la comisión de un delito.

"63. El Perú, por conducto de la jurisdicción militar, infringió el artículo 8.2 de la Convención, que consagra el principio de presunción de inocencia, al atribuir a la señora María Elena Loayza Tamayo la comisión de un delito diverso a aquel por el que fue acusada y procesada, sin tener competencia para ello, pues en todo caso, como antes se dijo, (supra, párr. 61) esa imputación solo correspondía hacerla a la jurisdicción ordinaria competente." 96

"76. La Corte pasa a analizar el alegato de la Comisión de que el proceso contra el señor Suárez Rosero violó el principio de presunción de inocencia establecido en el artículo 8.2 de la Convención Americana. Dicho artículo dispone que ' $[\mathrm{t}$ ]oda persona inculpada de delito tiene derecho a que se presuma su inocencia mientras no se establezca legalmente su culpabilidad...'.

77. Esta Corte estima que en el principio de presunción de inocencia subyace el propósito de las garantías judiciales, al afirmar la idea de que una persona es inocente hasta que su culpabilidad sea demostrada. De lo dispuesto en el artículo 8.2 de la Convención se deriva la obligación estatal de no restringir la libertad del detenido más allá de los límites estrictamente necesarios para asegurar que no impedirá el desarrollo eficiente de las investigaciones y que no eludirá la acción de la justicia, pues la prisión preventiva es una medida cautelar, no punitiva. Este concepto está expresado en múltiples instrumentos del derecho internacional de los derechos humanos y, entre otros, en el Pacto Internacional de Derechos Civiles y Políticos, que dispone que la prisión preventiva de las personas que hayan de ser juzgadas no debe ser la regla general (art. 9.3). En caso contrario se estaría cometiendo una injusticia al privar de libertad, por un plazo desproporcionado respecto de la pena que correspondería al delito imputado, a personas cuya responsabilidad criminal no ha sido establecida. Sería lo mismo que anticipar una pena a la sentencia, lo cual está en contra de principios generales del derecho universalmente reconocidos.

96 Corte IDH. Caso Loayza Tamayo. Sentencia de 17 de septiembre de 1997, párr. 63. 
78. La Corte considera que con la prolongada detención preventiva del señor Suárez Rosero, se violó el principio de presunción de inocencia, por cuanto permaneció detenido del 23 de junio de 1992 al 28 de abril de 1996 y la orden de libertad dictada en su favor el 10 de julio de 1995 no pudo ser ejecutada sino hasta casi un año después. Por todo lo expuesto, la Corte declara que el Estado violó el artículo 8.2 de la Convención Americana." ${ }^{97}$

Este principio debe ser respetado a lo largo del proceso y en consecuencia debe tener presente la excepcionalidad de la prisión preventiva, tal como lo señaló la Corte en el caso López Álvarez: ${ }^{98}$

"142. En su legislación interna y en la aplicación de la misma por las autoridades competentes, los Estados deben observar el carácter excepcional de la prisión preventiva y respetar el principio de presunción de inocencia a todo lo largo del procedimiento (supra párr. 67, 68 y 69).

143. En la presente sentencia se estableció que el señor Alfredo López Álvarez sufrió prisión preventiva en forma ilegal y arbitraria y permaneció privado de libertad hasta el 26 de agosto de 2003 (supra párr. 75 y 54.45).

144. La presunta víctima estuvo detenida por más de 6 años, sin que existieran razones que justificaran la prisión preventiva (supra párr. 74 y 78), lo que violó su derecho a que se le presumiera su inocencia del delito que le había sido imputado."

\subsection{Derecho de defensa}

El artículo 8.2 de la Convención establece un conjunto de garantías mínimas que permiten asegurar el derecho de defensa en el marco de los procesos penales. Entre estas garantías se encuentran:

1. El derecho del inculpado a la comunicación previa y detallada de la acusación formulada en su contra.

2. La concesión al inculpado del tiempo y de los medios adecuados para la preparación de su defensa.

3. El derecho del inculpado a defenderse por sí mismo o a través de un defensor de su elección o nombrado por el Estado.

${ }_{97}$ Corte IDH. Caso Suárez Rosero. Sentencia de 12 de noviembre de 1997, párr. 76-78.

98 Corte IDH. Caso López Álvarez, párr. 142-144. 
El derecho del inculpado a la comunicación previa y detallada de la acusación, cargo, imputación, razones, delitos o faltas por los cuales se le atribuye responsabilidad, es una garantía de carácter esencial para el ejercicio efectivo del derecho a la defensa, y debe ocurrir antes que el acusado o imputado rinda su primera declaración o efectúe su primer descargo, siendo de particular importancia cuando se adopten medidas que restrinjan su derecho a la libertad. En tal sentido, la Corte ha señalado en el caso López Álvarez:99

"149. El artículo 8.2.b de la Convención Americana ordena a las autoridades judiciales competentes notificar al inculpado la acusación formulada en su contra, sus razones y los delitos o faltas por los cuales se le atribuye responsabilidad. ${ }^{100}$ Para que este derecho satisfaga los fines que le son inherentes, es necesario que esa notificación ocurra antes de que el inculpado rinda su primera declaración ${ }^{101}$. Esta garantía es esencial para el ejercicio efectivo del derecho a la defensa. Es preciso considerar particularmente la aplicación de esta garantía cuando se adoptan medidas que restringen el derecho a la libertad personal, como en este caso.

150. En el presente caso, quedó demostrado que el señor Alfredo López Álvarez rindió su declaración indagatoria el 29 de abril de 1997, sin contar con la asistencia de un abogado defensor (supra párr. 54.17). De la prueba aportada consta que ese mismo día la presunta víctima nombró a su abogado defensor, cuya acreditación ante el Juzgado de Letras Seccional de Tela fue presentada el 30 de abril de 1997 y este Juzgado admitió el escrito el 2 de mayo de 1997 (supra párr. 54.18). El citado 30 de abril de 1997, el Ministerio Público presentó ante el Juzgado de Letras Seccional de Tela acusación por posesión, venta y tráfico de cocaína en contra del señor Alfredo López Álvarez y otras personas (supra párr. 54.19). Por lo que el señor López Álvarez rindió su declaración indagatoria sin conocer previa y detalladamente la acusación formulada en su contra."

Respecto al derecho del inculpado a defenderse por sí mismo o a través de un defensor de su elección o nombrado por el Estado, si una persona no tuvo oportunidad de rendir su indagatoria en presencia de su abogado, con quien tuvo comunicación días después de su detención, es evidente que no se le garantizó el derecho de contar con abogado defensor, tal como lo señaló la Corte en el caso López Álvarez: ${ }^{102}$

\footnotetext{
Ibid., párr. 149-150.

100 Cfr. Caso Palamara Iribarne, supra nota 15, párr. 225; Caso Acosta Calderón, supra nota 18, párr. 118, y Caso Tibi, supra nota 80, párr. 187.

101 Cfr. Caso Palamara Iribarne, supra nota 15, párr. 225; Caso Acosta Calderón, supra nota 18, párr. 118, y Caso Tibi, supra nota 80, párr. 187.

102 Corte IDH. Caso López Álvarez, párr. 152.
} 
"152. Se advierte que el señor López Álvarez no tuvo oportunidad de rendir declaración indagatoria en la presencia de su abogado, con quien tuvo comunicaciones algunos días después de su detención. En consecuencia, no se le garantizó el derecho de contar con abogado defensor conforme al artículo 8.2.d de la Convención.”

De acuerdo con la Corte, el derecho de defensa no se agota con la sola presencia de un abogado en las actuaciones policiales o judiciales, sino que se requiere que sea eficaz, es decir, que desarrolle sus funciones no solo formalmente, sino que lleve efectivamente la defensa encargada; ello solo será posible si la persona detenida cuenta con el tiempo y lugar adecuado para entrevistarse con su abogado, sin demora, sin interferencias, sin censura y en forma plenamente confidencial.

Si no se cuenta desde la fecha de detención con asistencia legal, o si se cuenta pero no con la asistencia de abogados de su elección, se viola el derecho de defensa. También se viola el derecho de defensa si los abogados tienen obstáculos para entrevistarse privadamente con sus defendidos ${ }^{103}$ (violación del art. 8.2.d).

Si el Estado no proporciona asistencia jurídica a los inculpados que carecen de ella, necesaria para ejercitar efectivamente, el recurso es ilusorio para ellos porque se les ha impedido ejercitarlos, con lo que se viola el derecho a la defensa (violación del artículo 8.2.e). ${ }^{104}$

\subsection{Derecho a la igualdad en el proceso. Igualdad de armas}

El artículo 1.1 de la Convención Americana sobre Derechos Humanos establece la obligación de los Estados Parte de respetar los derechos reconocidos en ella y "garantizar su libre y pleno ejercicio a toda persona que esté sujeta a su jurisdicción, sin discriminación alguna por motivos de raza, color, sexo, idioma, religión, opiniones políticas o de cualquier otra índole, origen nacional o social, posición económica, nacimiento o cualquier otra condición social". (Subrayado nuestro.)

Junto al reconocimiento del principio de no discriminación, la Convención Americana reconoce en su artículo $24^{\circ}$ el derecho de toda persona a la igualdad ante la ley. Sobre esta disposición, la Corte Interamericana ha señalado:

"En función del reconocimiento de la igualdad ante la ley, se prohíbe todo tratamiento discriminatorio de origen legal. De este modo, la prohibición de discriminación ampliamente contenida en el artículo 1.1 respecto de los derechos y

103 Corte IDH. Caso Castillo Petruzzi y otros. Sentencia de fondo, párr. 146-149.

104 Corte IDH. Caso Hilarie Constantine y otros. Sentencia de fondo, párr. 152. b. 
garantías estipulados por la Convención se extiende al derecho interno de los Estados Partes, de tal manera que es posible concluir que, con base en esas disposiciones (artículos 1.1 y 24), estos se han comprometido, en virtud de la Convención, a no introducir en su ordenamiento jurídico regulaciones discriminatorias referentes a la protección de la ley.”

Con base en estas consideraciones de la Corte, se puede concluir que el respeto al derecho a la igualdad ante la ley implica un mandato a toda autoridad estatal con potestad normativa para que se abstenga de establecer disposiciones que contengan preceptos discriminatorios.

En el ámbito del derecho al debido proceso, tanto el principio de no discriminación como el derecho a la igualdad ante la ley deben ser objeto de estricta observancia. Por eso, el artículo 8.2 de la Convención precisa que las garantías mínimas contenidas en esta disposición son derechos que deben ser ejercidos "en plena igualdad". Además, aunque no se señale expresamente, este criterio también debe ser aplicado respecto a las otras garantías previstas en el artículo 8 de la Convención, debido al mandato general de los artículos 1.1 (no discriminación) y 24 (igualdad ante la ley) contenidos en el mismo tratado.

De acuerdo con la Corte, "[u]na persona solo puede ser condenada por aquellos delitos por los que ha sido acusada y procesada, es decir, por los que ha podido defenderse en un proceso judicial llevado a cabo con todas las debidas garantías. ${ }^{105}$ Una situación contraria supondría una violación del Principio de Igualdad de Armas.

En el caso del Tribunal Constitucional, la Corte refirió la restricción del derecho de defensa que sufrieran los magistrados, pues cuando comparecieron ante la Comisión de Investigación del Parlamento, lo hicieron en virtud de denuncias formuladas por la Magistrada Revoredo y no por supuestas anomalías en el TC, por lo que no pudieron conocer de manera oportuna y completa de los cargos que se les formularon en ese acto, para la presentación de los descargos correspondientes. Tampoco se les permitió interrogar a los testigos, en cuyos testimonios se habían basado los congresistas para realizar el juicio político contra los 3 magistrados del TC.

\subsection{El derecho al plazo razonable de duración de un proceso}

¿Qué debe entenderse por plazo razonable? Para definir el plazo razonable, la Corte Interamericana recurrió a la jurisprudencia del Tribunal Europeo de $\mathrm{DH}$, que señala que debe tenerse en cuenta tres elementos para determinar la razonabilidad del plazo: ${ }^{106}$

105 Corte IDH. Caso Loayza Tamayo. Sentencia de fondo, párr. 63.

106 Corte IDH. Caso Genie Lacayo. Sentencia de fondo, párr. 77 y ss. 
a) La complejidad del caso.

b) La actividad procesal del interesado.

c) La conducta de las autoridades judiciales.

En el caso Suárez Rosero, la Corte consideró que "el transcurso de 4 años y 2 meses entre la detención y la sentencia sobre la apelación final de la víctima excede en mucho el principio del plazo razonable consagrado en la $\mathrm{CADH}$, correspondiendo al Estado exponer y probar la razón por la que se ha requerido más tiempo que el que sería razonable en principio para dictar sentencia definitiva en un caso particular de conformidad con los criterios indicados." ${ }^{107}$

En el caso Cantos contra la Argentina, la Corte observó en principio que "los diez años transcurridos entre la presentación de la demanda del señor Cantos ante la Corte Suprema de Justicia y la expedición de la sentencia de esta última que puso fin al proceso interno implican una violación de la norma sobre plazo razonable por parte del Estado". Agregó, sin embargo, que "si la conducta procesal del propio interesado en obtener justicia ha contribuido en algún grado a prolongar indebidamente la duración del proceso, difícilmente se configura en cabeza del Estado una violación de la norma sobre plazo razonable...". ${ }^{108}$

El principio del plazo razonable al que hace referencia los artículos 7.5 y 8.1 de la CADH tiene como finalidad impedir que los acusados permanezcan largo tiempo bajo acusación y asegurar que esta se decida prontamente. El proceso termina cuando se dicta sentencia definitiva y firme en el asunto, con lo cual se agota la jurisdicción. Particularmente, en materia penal, dicho plazo debe comprender todo el procedimiento, incluyendo los recursos de instancia que pudieran eventualmente presentarse. ${ }^{109}$

\subsubsection{Acciones de garantía}

En el marco de los recursos sencillos, rápidos y efectivos, la Corte ha sostenido que la institución procesal del amparo reúne las características necesarias para la tutela efectiva de los derechos fundamentales, es decir, ser sencilla y breve. La Ley 23506 en el Perú, fija plazos perentorios y máximos de 20 días para que los tribunales correspondientes emitan las resoluciones en cada una de las dos instancias que conocen la materia. En el caso del TC, las 3 víctimas interpusieron sus recursos de amparo los días 25 de julio y 1 de agosto de 1997, y ambos fueron denegados por la Sala Corporativa Especializada en Derecho Público de la Corte Superior de Justicia de Lima el 9 de febrero de 1998, es decir, más de 6 meses

107 Corte IDH. Caso Hilarie Constantine y otros. Sentencia de fondo, párr. 145.

108 Corte IDH. Caso Cantos. Sentencia de fundamento, párr. 57.

109 Corte IDH. Caso Suárez Rosero. Sentencia de fondo, párr. 70 a 73. 
después. El recurso extraordinario previsto por la $\mathrm{LO}$ del TC debe ser resuelto dentro de un plazo máximo de 20 días. Interpuesto dicho recurso por los magistrados, el TC confirmó la resolución de las instancias anteriores el 10 y 16 de julio de 1998, respectivamente, es decir, cinco meses después de haberse interpuesto. Así, de acuerdo con los criterios establecidos en esta materia por la Corte, excedió el principio de plazo razonable consagrado en la $\mathrm{CADH}$.

De acuerdo con la jurisprudencia de la Corte, en relación con el plazo razonable de los procesos judiciales, puede afirmarse que los procedimientos que se siguieron ante diversas instancias excedieron el plazo razonable consagrado en la $\mathrm{CADH}$, resultando tales recursos de amparo ilusorios e inefectivos si este retardo es producto de un retardo injustificado. ${ }^{110}$

\subsubsection{Proceso penal ordinario}

En el caso Las Palmeras, la Unidad Nacional de DH de la Fiscalía de la Nación se avocó al conocimiento de la causa el 14 de mayo de 1998, luego de que le fuera solicitado, con el fin de que se juzgara a los responsables de la muerte de las víctimas. A la fecha de la sentencia de la Corte Interamericana, es decir, el 6 de diciembre de 2001, "este no se ha concluido de manera que haya una resolución definitiva que identifique y sancione a los responsables. La investigación penal de dichos hechos lleva más de diez años, lo que demuestra que la administración de justicia no ha sido rápida ni efectiva”. ${ }^{111}$

Por ello señaló:

"63. La Corte ha establecido el criterio de que un período de cinco años transcurrido desde el momento del auto de apertura del proceso rebasaba los límites de la razonabilidad. ${ }^{112}$ Dicho criterio se aplica al presente caso."

En el caso de la Masacre del Plan de Sánchez, Guatemala aceptó su responsabilidad por, entre otros, las garantías judiciales a que se refiere el artículo 8.1 de la CADH, desde el 10 de diciembre de 1992, fecha en que se denunció la existencia de un cementerio clandestino en la aldea Plan de Sánchez y las autoridades judiciales iniciaron la causa No. 391/93 en el Juzgado de Primera Instancia de Salamá, Baja Verapaz, y en el Ministerio Público, donde le fue asignado el mismo número de expediente, conforme al sistema procesal penal vigente en esa época. El 6 de mayo de 1996, dicho Juez decretó el inicio del nuevo procedimiento bajo el No. 344/95. A la fecha de expedición de la sentencia -29 de abril de 2004-, se desconocen los resultados de dicho proceso. Han transcurrido 12 años y 7 años respectivamente, lo que, de acuerdo al criterio establecido por la Corte, rebasa los límites de razonabilidad. ${ }^{113}$

\footnotetext{
Corte IDH. Caso TC. Sentencia de fondo, párr. 91 y 93.

Corte IDH. Caso Las Palmeras. Sentencia de fondo de 6 de diciembre de 2001, párr. 55.

Cfr. Caso Genie Lacayo. Sentencia de 29 de enero de 1997. Serie C No. 30, párr. 81.

Corte IDH. Caso del Plan de Sánchez. Sentencia de fondo de 29 de abril de 2004, párr. 42.31 y ss.
} 


\subsection{Derecho a recurrir el fallo ante juez o tribunal superior}

El artículo 8.2.h de la Convención Americana sobre Derechos Humanos establece que toda persona tiene derecho "de recurrir del fallo ante juez o tribunal superior". Esta garantía implica la posibilidad de cuestionar una resolución dentro de la misma estructura jurisdiccional que la emitió.

La voluntad subyacente a la instauración de varios grados de jurisdicción significa reforzar la protección de los justiciables. Esto obedece a que toda resolución es fruto del acto humano, y que, por lo tanto, puede contener errores o generar distintas interpretaciones, ya sea en la determinación de los hechos o en la aplicación del Derecho. La revisión judicial permite, además, un control de los tribunales superiores sobre los de inferior jerarquía, estimulando la elaboración de resoluciones suficientemente fundamentadas, a fin de que no sean susceptibles de ser revocadas. Permite también que el superior revise la adecuación de la sentencia al Derecho.

Para la vigencia de esta garantía no basta el reconocimiento formal del derecho de apelación, sino que se precisa además que el órgano superior posea todas las características que son exigidas a los órganos judiciales, es decir, ser independiente, imparcial y previamente determinado por la ley y con poderes y atribuciones para que sus sentencias sean inmediatamente cumplidas.

En el caso Castillo Petruzzi, la Corte dijo:

"... el derecho de recurrir del fallo... no se satisface con la mera existencia de un órgano de grado superior al que juzgó y condenó al inculpado... es preciso que el tribunal superior reúna las características jurisdiccionales que lo legitiman para conocer del caso concreto... el proceso penal es uno solo a través de sus diversas etapas, tanto la correspondiente a la primera instancia como a la primera instancia como a las relativas a las instancias ulteriores... En consecuencia, el concepto del juez natural y el principio del debido proceso legal rigen a lo largo de esas etapas y se proyectan sobre las diversas instancias procesales. Si el juzgador de segunda instancia no satisface los requerimientos del juez natural, no podrá establecerse como legítima y válida la etapa procesal que se desarrolle ante él". ${ }^{114}$

En el caso Castillo Petruzzi, el tribunal de segunda instancia formaba parte de la estructura militar, por ello no tenía la independencia necesaria para actuar ni constituye un juez natural para el enjuiciamiento de civiles, y por ello violó el artículo 8.2.h de la Convención Americana. 
Se deben eliminar todos aquellos obstáculos que impidan ejercer este derecho, tales como la exigencia de demasiados requisitos formales o plazos muy breves para su interposición, etc.

El ejercicio del derecho de recurrir del fallo ante juez o tribunal superior, como es lógico suponer, implica que toda persona tiene derecho a disponer, en un plazo razonable y por escrito, de los fallos dictados en la determinación de su responsabilidad, debidamente motivados, a efectos de su posible apelación. En caso contrario, no se estaría concediendo la debida revisión de la sentencia, ni acceso oportuno a las razones del fallo, impidiéndose ejercer eficazmente el derecho de defensa. Esto implica asimismo que las resoluciones que se emitan en distintas instancias deben contener, con exactitud y claridad, las razones por las cuales se llega a la conclusión que ellas contienen, la valoración de las pruebas y los fundamentos jurídicos y normativos en que se basan.

\subsection{Prohibición de doble enjuiciamiento penal por los mismos hechos o non bis in idem}

El principio de non bis in ídem se encuentra contemplado en el artículo 8.4 de la Convención Americana sobre Derechos Humanos, en los siguientes términos: "El inculpado absuelto por una sentencia firme no podrá ser sometido a nuevo juicio por los mismos hechos".

La Corte Interamericana de Derechos Humanos ha precisado que este principio "busca proteger los derechos de los individuos que han sido procesados por determinados hechos para que no vuelvan a ser enjuiciados por los mismos hechos".

Por ello, la Corte ha señalado la "necesaria identidad de hechos, conducta o suceso a analizar, pero también sobre las personas tanto en el sentido activo como pasivo de la violación".

La Corte dijo que se entiende por hechos "la conducta o el suceso que implicaron la violación de un derecho humano".

Como "personas" considera a aquellos que tienen que ver con los sujetos activos y pasivos de la violación, principalmente con estos últimos, es decir, las víctimas, porque la titularidad de los derechos humanos reside en cada individuo y debe ser analizada asimismo de manera individual. ${ }^{115}$

Por ejemplo, el caso Neyra y el caso Durand, tramitados ante la Corte IDH, se relacionan con los mismos hechos: los sucesos ocurridos en el penal El Frontón, pero difieren en cuanto a las víctimas. 
En el caso Loayza Tamayo, la Corte desestimó el argumento del Estado sobre la inexistencia de la cosa juzgada, pues el Fuero Militar solo se había inhibido de conocer los hechos imputados a la señora Loayza a favor del Fuero Militar. En primer lugar, por un asunto técnico: el tribunal militar no utilizó en la sentencia el término inhibición sino absolución, como sí lo hizo respecto de otra persona. Para la Corte no se trató de un asunto de incompetencia. Para la Corte, la Sra. Loayza fue absuelta por el fuero militar no solo en el sentido técnico de la palabra absolución, sino que el fuero militar, en lugar de declararse incompetente, "conoció de los hechos, circunstancias y elementos probatorios del comportamiento atribuido, los valoró y resolvió absolverla". Por lo que al juzgarse a la Sra. Loayza por los mismos hechos por los que había sido absuelta en la jurisdicción militar, el Estado violó el artículo 8.4 de la CADH. ${ }^{116}$

"66. En cuanto a la denuncia de la Comisión sobre violación en perjuicio de la señora María Elena Loayza Tamayo de la garantía judicial que prohíbe el doble enjuiciamiento, la Corte observa que el principio de non bis in ídem está contemplado en el artículo 8.4 de la Convención en los siguientes términos:

‘4. El inculpado absuelto por una sentencia firme no podrá ser sometido a nuevo juicio por los mismos hechos."

Para la Corte, este principio busca "proteger los derechos de los individuos que han sido procesados por determinados hechos para que no vuelvan a ser enjuiciados por los mismos hechos. A diferencia de la fórmula utilizada por otros instrumentos internacionales de protección de derechos humanos (por ejemplo, el Pacto Internacional de Derechos Civiles y Políticos de las Naciones Unidas, artículo 14.7, que se refiere al mismo 'delito'), la Convención Americana utiliza la expresión 'los mismos hechos', que es un término más amplio en beneficio de la víctima".

La Corte determinó que la existencia de leyes que regulan los mismos tipos penales puede dar lugar a la violación del principio non bis in ídem:

“67. En el caso presente, la Corte observa que la señora María Elena Loayza Tamayo fue procesada en el fuero privativo militar por el delito de traición a la patria que está estrechamente vinculado al delito de terrorismo, como se deduce de una lectura comparativa del artículo 2, incisos a, b y c del Decreto-Ley No 25.659 (delito de traición a la patria) y de los artículos 2 y 4 del Decreto-Ley No 25.475 (delito de terrorismo). 
68. Ambos decretos-leyes se refieren a conductas no estrictamente delimitadas por lo que podrían ser comprendidas indistintamente dentro de un delito como en otro, según los criterios del Ministerio Público y de los jueces respectivos y, como en el caso examinado, de la "propia policía (DINCOTE)". Por lo tanto, los citados decretos-leyes en este aspecto son incompatibles con el artículo 8.4 de la Convención Americana."

La Corte concluyó que al juzgar a "la señora María Elena Loayza Tamayo en la jurisdicción ordinaria por los mismos hechos por los que había sido absuelta en la jurisdicción militar, el Estado peruano violó el artículo 8.4 de la Convención Americana”. Corte IDH. Caso Loayza Tamayo. Sentencia de 17 de septiembre de 1997, párr. 77.

\subsection{La publicidad del proceso o proceso público}

El artículo 8.5 de la Convención Americana sobre Derechos Humanos establece: "El proceso penal debe ser público, salvo en lo que sea necesario para preservar los intereses de la justicia”.

Esta garantía permite, entre otros aspectos, el control social de la actividad jurisdiccional y fomenta la participación de los ciudadanos en materia judicial, evitándose los procesos secretos.

Es contrario a la $\mathrm{CADH}$, la realización de procesos sin acceso del público, llevados con secretismo y aislamiento, entre ellos la audiencia, por no observar el derecho a la publicidad del proceso. En el caso Castillo Petruzzi, "la Corte considera probado que los procesos militares de civiles supuestamente incursos en delitos de traición a la patria son desarrollados por jueces y fiscales 'sin rostro', y conllevan una serie de restricciones que los hacen violatorios del debido proceso legal. En efecto se realizaron en un recinto militar, al que no tiene acceso el público...". ${ }^{117}$

En el caso Cantoral Benavides, la Corte observó que los juicios son llevados en establecimientos penitenciarios y en ambientes acondicionados para que los jueces, fiscales y auxiliares de justicia no puedan ser identificados visual o auditivamente por los procesados y abogados defensores; que varias audiencias se llevaron a cabo en el interior de los establecimiento carcelarios, por lo que no reunían las condiciones de publicidad que exige el art. 8.5 de la $\mathrm{CADH}^{118}$.

117 Corte IDH. Caso Castillo Petruzzi y otros. Sentencia sobre el fondo, párr. 167 y 168.

118 Corte IDH. Caso Cantoral Benavides. Sentencia sobre el fondo, párr. 145 -149. 


\section{RELACIÓN ENTRE EL DEBIDO PROCESO Y LA PROTECCIÓN JUDICIAL}

La Corte Interamericana de Derechos Humanos ha establecido en su jurisprudencia la existencia de una "ineludible" relación entre el derecho al debido proceso y el derecho a la protección judicial para garantizar la justicia y la no impunidad. Así lo han entendido los jueces Cancado y Pacheco: ${ }^{119}$

“17. La relación de los artículos 8(1) y 25(1) con el artículo 1(1) de la Convención en el presente caso es ineludible. Recuérdese que en el reciente caso de los 'Niños de la Calle' (Sentencia sobre el fondo, del 19.11.1999), relativo a Guatemala, esta Corte ha establecido que 'el artículo 25 se encuentra íntimamente ligado con la obligación general del artículo 1(1) de la Convención Americana, al atribuir funciones de protección al derecho interno de los Estados Partes, de lo cual se desprende que el Estado tiene la responsabilidad de diseñar y consagrar normativamente un recurso eficaz, pero también la de asegurar la debida aplicación de dicho recurso por parte de sus autoridades judiciales'. ${ }^{120}$

18. En efecto, no hay cómo negar la estrecha vinculación entre la obstaculización del deber de investigación y la persistencia de la impunidad. En la misma Sentencia sobre el caso de los "Niños de la Calle", la Corte señaló que, para la determinación de la responsabilidad internacional de los Estados por violaciones de los derechos humanos, debía efectuar "un examen del conjunto de las actuaciones judiciales internas para obtener una percepción integral de tales actuaciones, y establecer si resulta o no evidente que dichas actuaciones contravienen los estándares sobre el deber de investigar y derecho a ser oído y a un recurso efectivo que emergen de los artículos 1(1), 8 y 25 de la Convención." 121

\section{EFECTOS DE LA VIOLACIÓN DEL DEBIDO PROCESO}

La validez de una sentencia depende de la validez del proceso.

"Todo proceso está integrado por actos jurídicos que guardan entre sí relación cronológica, lógica y teleológica. Unos son soporte o supuesto de los otros y todos se ordenan a un fin supremo y común: la solución de la controversia por medio de una sentencia. Los actos procesales corresponden al género de los actos jurídicos, y

119 Corte IDH: Caso Las Palmeras. Sentencia de 6 de diciembre de 2001, Voto Razonado Conjunto de los Jueces Cancado y Pacheco, párr. 17-18.

120 Corte IDH, Serie C, No. 63, p. 95, párr. 237.

121 Corte IDH, Serie C, No. 63, p. 90, párr. 223-224 (énfasis acrecentado). 
por ello se encuentran sujetos a las reglas que determinan la aparición y los efectos de aquellos. Por ende, cada acto debe ajustarse a las normas que presiden su creación y le confieren valor jurídico, presupuesto para que produzca efectos de ese carácter. Si ello no ocurre, el acto carecerá de validez y no producirá tales efectos. La validez de cada uno de los actos jurídicos influye sobre la validez del conjunto, puesto que en este cada uno se halla sustentado en otro precedente y es, a su turno, sustento de otros más. La culminación de esa secuencia de actos es la sentencia, que dirime la controversia y establece la verdad legal, con autoridad de cosa juzgada.

... si los actos en que se sostiene la sentencia están afectados por vicios graves, que los privan de la eficacia que debieran tener en condiciones normales, la sentencia no subsistirá. Carece de soporte necesario". ${ }^{122}$ 